\title{
An update of the structure and 16S rRNA gene sequence-based definition of higher ranks of the class Actinobacteria, with the proposal of two new suborders and four new families and emended descriptions of the existing higher taxa
}

\author{
Correspondence \\ Wen-Jun Li \\ wjli@ynu.edu.cn \\ Erko Stackebrandt \\ erko@dsmz.de
}

\author{
Xiao-Yang Zhi, ${ }^{1}$ Wen-Jun $\mathrm{Li}^{1}$ and Erko Stackebrandt ${ }^{2}$ \\ ${ }^{1}$ The Key Laboratory for Microbial Resources of the Ministry of Education and Laboratory for \\ Conservation and Utilization of Bio-Resources, Yunnan Institute of Microbiology, Yunnan \\ University, Kunming 650091, PR China \\ ${ }^{2}$ DSMZ - Deutsche Sammlung von Mikroorganismen und Zellkulturen GmbH, Inhoffenstrasse 7b, \\ D-38124 Braunschweig, Germany
}

\section{INTRODUCTION}

The class Actinobacteria constitutes one of the main phyla within the Bacteria (Ludwig \& Klenk, 2001) on the basis of its branching position in $16 \mathrm{~S}$ rRNA gene trees. Besides the phylogeny of the 16S rRNA gene, some conserved indels in $23 \mathrm{~S}$ rRNA and protein (e.g. cytochrome- $c$ oxidase I, CTP synthetase and glutamyl-tRNA synthetase) sequences

Abbreviations: ML, maximum-likelihood; MP, maximum-parsimony; NJ, neighbour-joining.

Trees based on 16S rRNA gene sequences showing relationships between members of the Corynebacterineae using the neighbour-joining method and within the Actinobacteria using the maximum-parsimony and maximum-likelihood methods and a tree based on concatenated sequences of seven housekeeping genes are available as supplementary material with the online version of this paper. support the distinctness of members of the class from all other bacteria (Gao \& Gupta, 2005). The initial hierarchical classification system of the Actinobacteria (Stackebrandt et al., 1997) embraced 95 genera, belonging to 30 families and 10 suborders. The phylogenetic relationships of taxa higher than the rank of genus of the Actinobacteria were deduced from the clustering of genera in a neighbourjoining dendrogram. The distinction of these ranks from each other was based solely upon taxon-specific $16 \mathrm{~S}$ rRNA signature nucleotides considered. Phenotypic characteristics, such as chemotaxonomic, morphological and physiological properties, were not taken into account in the delineation of higher ranks. Signature nucleotide patterns, often used in the forthcoming volume 4 of the second edition of Bergey's Manual of Systematic Bacteriology at the level of genera and families, are a molecular basis for 
positional differences within the 16S rRNA. It is not the 'truth', but an attempt to bring rational order to a group of related organisms, at least for the time being.

It was already obvious in 1997 that the composition of these signatures might change when new sequences were added to the databases. The analysis and determination of signatures were based on published 16S rRNA gene sequences of type strains. 16S rRNA gene sequences of uncultured micro-organisms were not considered, as the quality of such sequences cannot be checked. Nevertheless, the indication of the presence of novel taxa forecast an increase in the phylogenetic richness of the phylum. The availability of novel described taxa is the main reason why patterns of $16 \mathrm{~S}$ rRNA gene sequence signatures need to be updated regularly.

To date, 219 genera (in 48 families, including some new genera, such as Catelliglobosispora, Devriesea, Fodinicola, Glaciibacter, Haloactinospora, Hamadaea, Humibacillus, Klugiella, Marihabitans, Pseudosporangium and Sciscionella, proposed in papers in press in the International Journal of Systematic and Evolutionary Microbiology at the time of writing) have been accommodated in the class Actinobacteria, phylum Actinobacteria. The subclass Sphaerobacteridae was removed from the phylum Actinobacteria with the reclassification of Sphaerobacter thermophilus as a member of the class Thermomicrobia, phylum Chloroflexi (Hugenholtz \& Stackebrandt, 2004). The description of the families Catenulisporaceae (Busti et al., 2006) and Actinospicaceae (Cavaletti et al., 2006) resulted in the description of an eleventh suborder, Catenulisporinae (Cavaletti et al., 2006), in the order Actinomycetales. As the number of $16 \mathrm{~S}$ rRNA gene sequences deposited in public databases has increased tremendously, decisions about which 16S rRNA gene sequence nucleotides define taxonomic ranks were likely to be affected. Above all, this was expected to happen in those genera and higher taxa that included only a single type strain in 1997.

Given that scientists actually use the set of signatures for decisions on the description of higher taxa, an update of the phylogenetic structure of the class Actinobacteria is called for. In this paper, we update the structure of higher ranks of the class Actinobacteria and provide a set of $16 \mathrm{~S}$ rRNA signature nucleotides between the ranks of family and subclass. Some novel taxa are also proposed as a result of the phylogenetic analysis and signature patterns.

\section{METHODS}

$16 S$ rRNA gene sequence and alignment. A total of $264216 \mathrm{~S}$ rRNA gene sequences of members of the phylum Actinobacteria were obtained from the Ribosomal Database Project (Cole et al., 2007). Sequences shorter than $1300 \mathrm{bp}$ and those containing ambiguous nucleotide sequences were excluded from the database. Sequences of each family were downloaded, together with an Escherichia coli $16 \mathrm{~S}$ rRNA gene sequence (GenBank accession number J01695), in separate files. Alignments were carried out using the CLUSTAL $\mathrm{W}$ tool in MEGA version 4.0 (Tamura, et al., 2007). The alignments were then corrected manually using the program BioEdit (Hall, 1999).
Phylogenetic analyses. For reconstruction of the phylogenetic dendrograms, the type species of the type genus of each family were selected as representative. The phylogenetic dendrograms obtained represented a general overview at the higher-taxon level but do not display the branching order at the species level. As lower-taxon branching orders are susceptible to changes depending on the dataset, i.e. the number of sequences available for a given genus, the database was restricted to the type strain of the type species of the type genus of each family. All columns containing gaps in the alignment were deleted manually. The neighbour-joining (NJ), maximum-parsimony (MP) and maximum-likelihood (ML) algorithms were used in phylogenetic tree building. Phylogenetic dendrograms were reconstructed by using the DNAPARS and DNAML programs in the PHYLIP package (Felsenstein, 2005) and MEGA version 4.0 (Tamura, et al., 2007). The distance matrix was produced on the basis of Kimura's two-parameter model (Kimura, 1980). Bootstrap analysis (Felsenstein, 1985) was done with 1000 replicates except in ML, where only 100 replicates were generated.

Deduced amino acid sequences of the proteins AtpD, DnaA, DnaG, DnaK, GyrB, RecA and RpoB were retrieved from the genomes of the following strains for multilocus sequence analysis (MLSA) in order to show the phylogenetic relationships of main groups of Actinobacteria: Acidothermus cellulolyticus $11 \mathrm{~B}^{\mathrm{T}}$, Actinomyces odontolyticus ATCC 17982, Arthrobacter aurescens TC1, Arthrobacter sp. FB24, Bifidobacterium adolescentis ATCC $15703^{\mathrm{T}}$, Bifidobacterium longum NCC2705, Clavibacter michiganensis subsp. michiganensis NCPPB 382, Corynebacterium efficiens YS- $314^{\mathrm{T}}$, Corynebacterium glutamicum R, Frankia alni ACN14a, Frankia sp. CcI3, Frankia sp. EAN1pec, Janibacter sp. HTCC2649, Kineococcus radiotolerans SRS30216 ${ }^{\mathrm{T}}$, Leifsonia xyli subsp. xyli CTCB07, Mycobacterium smegmatis MC2 155, Mycobacterium ulcerans Agy99, Nocardia farcinica IFM 10152, Nocardioides sp. JS614, Propionibacterium acnes KPA171202, Renibacterium salmoninarum ATCC $33209^{\mathrm{T}}$, Rhodococcus sp. RHA1, Rubrobacter xylanophilus DSM $9941^{\mathrm{T}}$, Saccharopolyspora erythraea NRRL $2338^{\mathrm{T}}$, Salinispora arenicola CNS-205, Salinispora tropica $\mathrm{CNB}-440^{\mathrm{T}}$, Streptomyces avermitilis $\mathrm{MA}-4680^{\mathrm{T}}$, Streptomyces coelicolor A3(2), Thermobifida fusca YX and Tropheryma whipplei TW08/27. The corresponding proteins in the genomes of Bacillus clausii KSMK16, Clostridium acetobutylicum ATCC $824^{\mathrm{T}}$ and Escherichia coli K-12 were used as outgroups. The incongruence length difference (ILD) test (1000 randomizations of datasets; Farris et al., 1995) was performed using PAUP ${ }^{\star}$ version $4.0 \mathrm{~b} 10$ (Swofford, 2002). Hierarchical likelihood-ratio tests were conducted with a batch file supplied with MODELTEST 3.7 (Posada \& Hasegawa, 1998) to provide the evolutionary models used in NJ methods.

Signature nucleotide analyses. The complete dataset used for the analyses described in this study contained information on more than 1300 unambiguous nucleotide positions present in all sequences between positions 100 and 1400 (Escherichia coli sequence; Brosius et al., 1978). Consensus sequences were calculated by using BioEdit software (Hall, 1999) for each family and used to compare with other families in the same suborder. The threshold consensus value for inclusion of a given nucleotide in a dataset at the family level was $95 \%$. Variable positions $(<95 \%)$ at the level of families and suborders were treated as gaps. Only highly conservative sites were used to detect group-specific signature nucleotides. Positional nucleotide numerical summary (one function of BioEdit) can provide intuitive and tractable statistical data. This approach allows simultaneous identification of those positions that are either above or below the threshold consensus value of $95 \%$.

\section{RESULTS AND DISCUSSION}

The hierarchical classification system based on the phylogeny of $16 \mathrm{~S}$ rRNA gene sequences does not change the 
current descriptions of species and genera, which are in most cases based upon morphological, chemotaxonomic and physiological characteristics (Stackebrandt et al., 1997). These taxa, which provide the working basis for taxonomists, have been revised to constitute phylogenetically coherent taxonomic units in the past several decades. However, the descriptions of taxa above the genus level have not been revisited in the past 10 years. Signature nucleotides are derivatives of the classification process (Stackebrandt et al., 1997). As most signatures are involved in higher order structure, their use in classification expands information from the primary structure (phylogenetic trees) to information on secondary structure idiosyncrasies. However, it is obvious that, at any rank, a significant increase in numbers of species in any of the phylogenetic lineages leads to a decrease in the number of signatures. One example is obvious in the suborder Corynebacterineae: the differences between signature patterns of the families Nocardiaceae and Gordoniaceae disappear with the introduction of the genera Millisia, Skermania and Williamsia. These three genera differed significantly from members of the family Gordoniaceae at signature sites 70:98, $293: 304,307,661: 744,824: 876,825: 875,1002: 1038$ and $1124: 1149$. The phylogenetic position of the genera Millisia, Skermania and Williamsia is located between the families Nocardiaceae and Gordoniaceae (Supplementary Fig. S1, available in IJSEM Online). Hence, the families Nocardiaceae and Gordoniaceae are proposed here to be combined in an emended family Nocardiaceae.

In the past, the genera Actinocorallia, Actinokineospora, Excellospora, Kineococcus and Kineosporia were excluded from the taxonomic system of Actinobacteria because they had either not been investigated by $16 \mathrm{~S}$ rRNA gene sequence analysis or their phylogenetic affiliation remained undetermined because of uncertainties about their phylogenetic position. The relationship between the members of the family Thermomonosporaceae was clarified on the basis of $16 \mathrm{~S}$ rRNA gene, 16S-23S rRNA internal transcribed spacer and $23 \mathrm{~S}$ rRNA gene sequences and chemotaxonomic analyses (Zhang et al., 2001). As a consequence, the description of the genus Actinocorallia was emended and it was assigned to the family Thermomonosporaceae. Simultaneously, the genus Excellospora lost its taxonomic status when the type species Excellospora viridilutea was transferred to the genus Actinomadura as Actinomadura viridilutea (Zhang et al., 2001). Phylogenetic analysis of the genera Actinokineospora, Actinosynnema, Lentzea and Saccharothrix showed that they are members of the same clade, and distinct from the Pseudonocardiaceae (Labeda \& Kroppenstedt, 2000). The family Actinosynnemataceae was established to accommodate the genera Actinokineospora, Actinosynnema, Lentzea and Saccharothrix.

Subsequent studies showed that the genera Kineococcus and Kineosporia form a cluster with a high bootstrap value (98\%) and did not belong to any previously described suborder (Kudo et al., 1998). Furthermore, the evolutionary distance between the two genera seems to be great enough to separate them at the family level. The genus Quadrisphaera was proposed by Maszenan et al. (2005) and assigned to the suborder Frankineae at that time. In fact, the genera Kineococcus, Kineosporia and Quadrisphaera form a distinct clade (Fig. 1) and share neighbourhood with the suborder Micrococcineae when more sequences from each representative were used in reconstruction of the phylogenetic dendrogram. The genera Kineococcus, Kineosporia and Quadrisphaera differed from the suborder Micrococcineae at the sites $1165: 1171$ (G-A vs G-C) and 1163:1173 ( $\mathrm{G}-\mathrm{U}$ vs $\mathrm{G}-\mathrm{C}$ ). Therefore, Kineosporiineae subord. nov. and Kineosporiaceae fam. nov. are proposed to accommodate the genera Kineococcus, Kineosporia and Quadrisphaera. Similarly, the genus Actinopolyspora forms a deep separate branch in the order Actinomycetales. Actinopolysporineae subord. nov. and Actinopolysporaceae fam. nov. are proposed to accommodate the genus Actinopolyspora.

The genus Cryptosporangium was proposed by Tamura et al. (1998), and its phylogenetic position was located in the suborder Frankineae. Although the branch was not supported by a high bootstrap value, the relationships with other families remained stable. Noticeably, the signature nucleotides of the genus Cryptosporangium differed distinctly from those of other families. Consequently, the genus Cryptosporangium should represent a novel family of the suborder Frankineae. Cryptosporangiaceae fam. nov. is proposed to accommodate the genus Cryptosporangium. The genera Beutenbergia (Groth et al., 1999b), Georgenia (Altenburger et al., 2002a) and Salana (von Wintzingerode et al., 2001) were assigned to the suborder Micrococcineae as novel lineages at the genus level; Beutenbergiaceae fam. nov. is proposed to accommodate the genera Beutenbergia, Georgenia and Salana.

The phylogenetic position of the genus Thermobispora was unclear when it was proposed by Wang et al. (1996). Even additional analysis, performed to clarify the taxonomic position of Thermobispora, did not lead to a reliable higherorder classification. Though the family-level affiliation of Thermobispora still can not be determined, the genus should be assigned to the suborder Streptosporangineae. In the following updated phylogenetic structure of the class Actinobacteria, the genus Thermobispora was excluded.

The phylogenetic relatedness of taxa above the genus level is shown in Fig. 1. High bootstrap values are found at deep branching points of lineages such as nodes that separate orders. In contrast, low bootstrap values are found at nodes that separate some suborders and most families of the order Actinomycetales. The class Actinobacteria contains the subclasses Acidimicrobidae, Rubrobacteridae, Coriobacteridae and Actinobacteridae. In comparison with the dendrogram shown in 1997, the phylogenetic relatedness of these lineages (Fig. 1) has been affected by the introduction of novel families described in the past decade.

The order Rubrobacterales constitutes one of the deepest branches within the phylum Actinobacteria, followed by the 


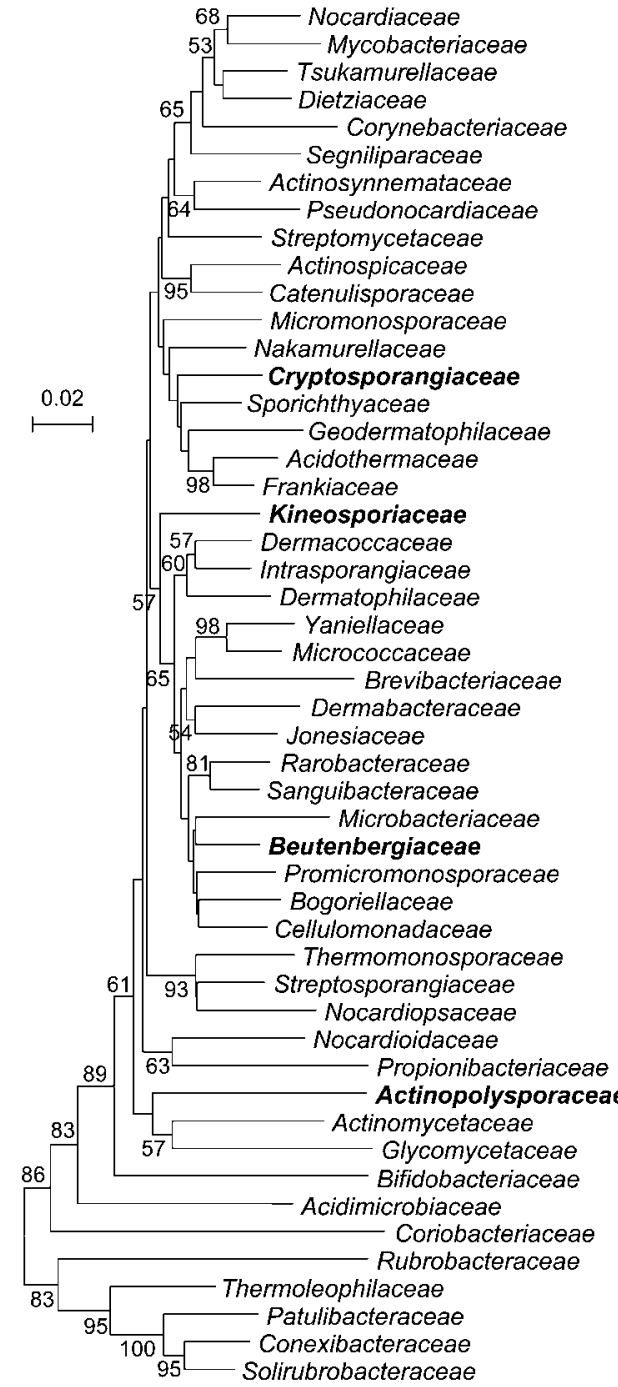

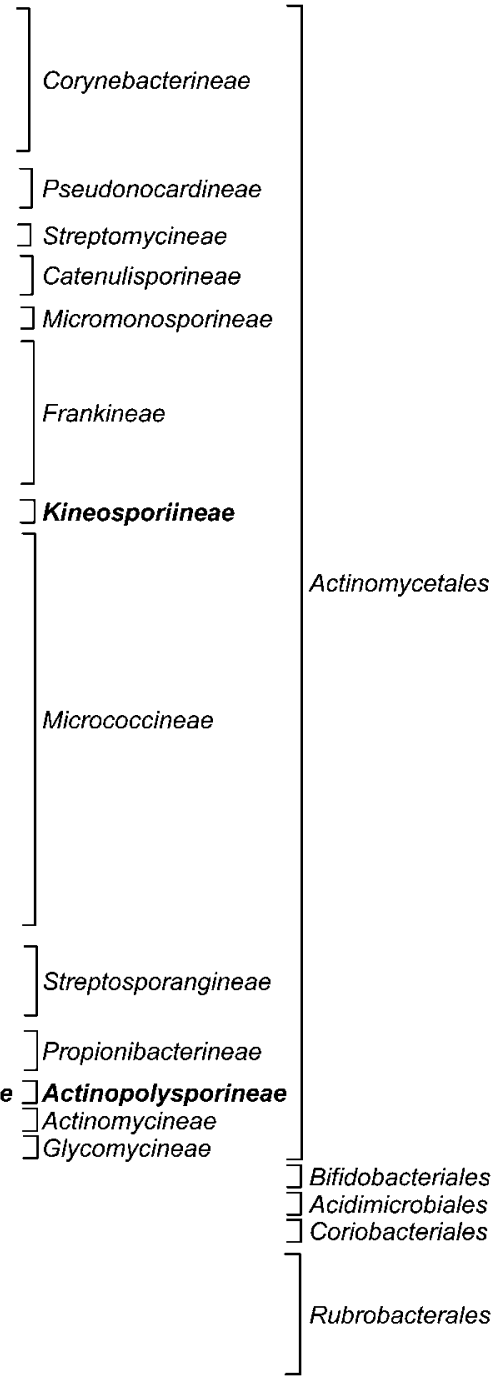

Fig. 1. Intraclass relatedness of the class Actinobacteria showing the presence of five orders based on 16S rRNA gene sequence comparison. The phylogenetic relatedness of the families of the class Actinobacteria is outlined. Taxa newly described in this paper are highlighted in bold. Bootstrap values of $50 \%$ or more are indicated at branch points. Bar, 2 substitutions per 100 nucleotide positions. lineages of the orders Coriobacteriales and Acidimicrobiales. A comparative genomic study has provided convincing evidence that the Rubrobacterales is part of the phylum Actinobacteria and forms an outgroup of the other actinobacteria (Gao et al., 2006). Within the subclass Actinobacteridae, the family Bifidobacteriaceae forms a deep-branching lineage. The placement of the bifidobacteria within the Actinobacteria and their deep branching within this phylum have also been strongly supported by comparative genomic studies (Gao et al., 2006; Ventura et al., 2007). The phylogenetic relationships among deeply branching lineages within the phylum Actinobacteria are stable and supported by high bootstrap values in the NJ tree.

The topological structures of phylogenetic dendrograms calculated on the basis of three different algorithms were compared with each other. The families belonging to the suborder Frankineae were separated into distinct clades in the MP and ML trees (Supplementary Figs S2 and S3). The suborders Actinomycineae, Glycomycineae and Actinopolysporineae subord. nov. formed a distinct branch and were positioned within the suborder Micrococcineae in the MP and ML trees. Similarly, the order Bifidobacteriales was positioned within the suborder Micrococcineae in the MP and ML trees. This confirms the study of Gao et al. (2006), indicating that members of Bifidobacteriales are related to the Micrococcineae. All other families and suborders were positioned at similar branches in NJ, MP and ML trees (Fig. 1 and Supplementary Figs S2 and S3). Phylogenetic analysis based on the $16 \mathrm{~S}$ rRNA gene sequence as well as comparative genomic studies indicate that the suborders Streptomycineae, Frankineae, Pseudonocardineae and Corynebacterineae form late-branching groups within the Actinobacteria (Gao et al., 2006).

The $P$ value generated from the ILD analysis was 0.001 , which indicated that the combination of data would improve the phylogenetic accuracy. Hierarchical likelihood-ratio tests were performed in the selection of the evolutionary model and in the optimization of parameters such as base frequencies, the substitution model and among-site rate variation. The TrN model (Tamura \& Nei, $1993)$ with gamma $(\Gamma)$ variation and a proportion of invariable sites (I) was used in the NJ analysis. The MLSA 
result (Supplementary Fig. S4) indicates that the suborders Streptomycineae, Micromonosporineae, Frankineae, Pseudonocardineae and Corynebacterineae form late-branching groups within the Actinobacteria, as found in comparative genomic studies and 16S rRNA gene sequence phylogeny. The strains Actinomyces odontolyticus ATCC 17982, Bifidobacterium adolescentis ATCC $15703^{\mathrm{T}}$ and Bifidobacterium longum NCC2705 form a clade within the suborder Micrococcineae (see above; viz. Janibacter sp. HTCC2649, Arthrobacter aurescens TC1, Arthrobacter sp. FB24, Renibacterium salmoninarum R, Tropheryma whipplei TW08/27, Clavibacter michiganensis subsp. michiganensis NCPPB 382 and Leifsonia xyli subsp. xyli CTCB07). Similarly, Kineococcus radiotolerans SRS30216 ${ }^{\mathrm{T}}$ and Janibacter sp. HTCC2649 form a clade within the Micrococcineae. Nevertheless, as long as the 16S rRNA gene plays the most decisive role in decisions on higher-order structures, topologies of trees from genes coding for housekeeping proteins may be used to support or contradict such arguments; eventually, when genome sequences become available for all type strains, genes other than the 16S rRNA gene may reveal their potential to reflect better the phylogeny of the Actinobacteria.

The signatures given below for higher taxa were chosen for their presence in more than $95 \%$ (the same criterion as used by Stackebrandt et al., 1997) of the members of the respective taxon. The genus was treated as the lowest unit for the definition of signature nucleotides. An updated description of the hierarchical classification system of the class Actinobacteria is proposed as follows. Some signature nucleotides are in common with the previous patterns. About 207 signature nucleotides proposed by Stackebrandt et al. (1997) are not valid today.

\section{Emended description of the subclass Acidimicrobidae Stackebrandt et al. 1997}

The pattern of 16S rRNA signatures consists of nucleotides at positions $242: 284(\mathrm{U}-\mathrm{G}), 291: 309(\mathrm{U}-\mathrm{A}), 316: 337(\mathrm{C}-$ G), $819(\mathrm{U}), 952: 1229(\mathrm{C}-\mathrm{G})$ and $1115: 1185(\mathrm{U}-\mathrm{G})$. The subclass contains the order Acidimicrobiales. The nomenclatural type is the order Acidimicrobiales Stackebrandt et al. 1997.

\section{Emended description of the order Acidimicrobiales Stackebrandt et al. 1997}

The 16S rRNA nucleotide signature pattern is as that of the subclass. The order contains the family Acidimicrobiaceae. The nomenclatural type is the genus Acidimicrobium Clark and Norris 1996.

\section{Emended description of the family Acidimicrobiaceae Stackebrandt et al. 1997}

The 16S rRNA nucleotide signature pattern is as that of the subclass. The family contains the type genus Acidimicrobium.

\section{Emended description of the subclass Coriobacteridae Stackebrandt et al. 1997}

The pattern of $16 \mathrm{~S}$ rRNA signatures consists of nucleotides at positions 242:284 (C-G), 291:309 (C-G), 316:337 (U-G), 819 (A), 952:1229 (U-A) and 1115:1185 (C-G). The subclass contains the order Coriobacteriales. The nomenclatural type is the order Coriobacteriales Stackebrandt et al. 1997.

\section{Emended description of the order Coriobacteriales Stackebrandt et al. 1997}

The 16S rRNA nucleotide signature pattern is as that of the subclass. The order contains the family Coriobacteriaceae. The nomenclatural type is the genus Coriobacterium Haas and König 1988.

\section{Emended description of the family Coriobacteriaceae Stackebrandt et al. 1997}

The 16S rRNA nucleotide signature pattern is as that of the subclass. The family contains the type genus Coriobacterium, as well as the genera Atopobium Collins and Wallbanks 1993 (effective publication Collins \& Wallbanks, 1992), Adlercreutzia Maruo et al. 2008, Collinsella Kageyama et al. 1999, emend. Kageyama and Benno 2000, Cryptobacterium Nakazawa et al. 1999, Denitrobacterium Anderson et al. 2000, Eggerthella Wade et al. 1999, Olsenella Dewhirst et al. 2001 and Slackia Wade et al. 1999.

\section{Emended description of the subclass Rubrobacteridae Rainey et al. 1997}

The pattern of $16 \mathrm{~S}$ rRNA signatures consists of nucleotides at positions $242: 284(\mathrm{C}-\mathrm{G}), 291: 309(\mathrm{U}-\mathrm{A}), 316: 337$ (CG), 819 (A), $952: 1229$ (U-A) and 1115:1185 (C-G). The subclass contains the order Rubrobacterales. The nomenclatural type is the order Rubrobacterales Rainey et al. 1997.

\section{Emended description of the order Rubrobacterales Rainey et al. 1997}

The 16S rRNA nucleotide signature pattern is as that of the subclass. The order contains the families Rubrobacteraceae, Conexibacteraceae, Patulibacteraceae, Solirubrobacteraceae and Thermoleophilaceae. The nomenclatural type is the genus Rubrobacter Suzuki et al. 1989 (effective publication Suzuki et al., 1988).

\section{Emended description of the family Rubrobacteraceae Rainey et al. 1997}

The pattern of $16 \mathrm{~S}$ rRNA signatures consists of nucleotides at positions $63: 104(\mathrm{C}-\mathrm{G}), 144: 178(\mathrm{G}-\mathrm{C}), 145: 177(\mathrm{G}-$ C), 293:304 (G-U), 377:386 (G-C), 409:433 (C-G), 657:749 (G-C), 681:709 (C-G), 722:733 (G-G), 953:1228 (U-A), 954:1226 (C-G), 1051:1207 (C-G) and $1313: 1324(\mathrm{U}-\mathrm{A})$. The family contains the type genus Rubrobacter. 


\section{Emended description of the family Conexibacteraceae Stackebrandt 2005 (effective publication Stackebrandt, 2004)}

The pattern of 16S rRNA signatures consists of nucleotides at positions $144: 178(\mathrm{U}-\mathrm{A}), 145: 177(\mathrm{U}-\mathrm{A}), 293: 304(\mathrm{G}-$ C), 377:386 (C-G), 408:434 (A-U), 418:425 (U-A), $590: 649$ (U-A) and 600:638 (U-G). The family contains the type genus Conexibacter Monciardini et al. 2003.

\section{Emended description of the family Patulibacteraceae Takahashi et al. 2006}

The pattern of $16 \mathrm{~S}$ rRNA signatures consists of nucleotides at positions $52: 359(\mathrm{C}-\mathrm{G}), 144: 178(\mathrm{C}-\mathrm{G}), 293: 304(\mathrm{G}-$ C), 377:386 (C-G), 502:543 (G-C), 590:649 (U-A), $600: 638$ (U-G) and 1354:1368 (U-G). The family contains the type genus Patulibacter Takahashi et al. 2006.

\section{Emended description of the family \\ Solirubrobacteraceae Stackebrandt 2005 (effective publication Stackebrandt, 2004)}

The pattern of $16 \mathrm{~S}$ rRNA signatures consists of nucleotides at positions 52:359 (C-G), 144:178 (C-G), 145:177 (CG), $293: 304(\mathrm{G}-\mathrm{C}), 590: 649(\mathrm{C}-\mathrm{G})$ and $600: 638(\mathrm{C}-\mathrm{G})$. The family contains the type genus Solirubrobacter Singleton et al. 2003.

\section{Emended description of the family Thermoleophilaceae Stackebrandt 2005 (effective publication Stackebrandt, 2004)}

The pattern of 16S rRNA signatures consists of nucleotides at positions $52: 359(\mathrm{C}-\mathrm{G}), 144: 178(\mathrm{C}-\mathrm{G}), 145: 177(\mathrm{C}-$ G), 293:304 (G-U), 370:391 (G-C), 377:386 (C-G), $590: 649(\mathrm{C}-\mathrm{G}), 600: 638(\mathrm{C}-\mathrm{G}), 670: 736(\mathrm{G}-\mathrm{C}), 681: 709$ (C-G), $941: 1342(\mathrm{G}-\mathrm{C})$ and 1311:1326 (G-C). The family contains the type genus Thermoleophilum Zarilla and Perry 1986 (effective publication Zarilla \& Perry, 1984).

\section{Emended description of the subclass Actinobacteridae Stackebrandt et al. 1997}

The pattern of 16S rRNA signatures consists of nucleotides at positions $242: 284(\mathrm{U}-\mathrm{G}), 291: 309(\mathrm{C}-\mathrm{G}), 316: 337$ (U$\mathrm{G}), 819(\mathrm{G}), 952: 1229(\mathrm{C}-\mathrm{G})$ and $1115: 1185(\mathrm{U}-\mathrm{G})$. The subclass contains the orders Bifidobacteriales and Actinomycetales. The nomenclatural type is the order Actinomycetales Buchanan 1917.

\section{Emended description of the order Bifidobacteriales Stackebrandt et al. 1997}

The pattern of $16 \mathrm{~S}$ rRNA signatures consists of nucleotides at positions $688: 699(\mathrm{~A}-\mathrm{U}), 701(\mathrm{U}), 823: 877(\mathrm{~A}-\mathrm{U})$ and 1060:1197 (C-G). The order contains the family Bifidobacteriaceae. The nomenclatural type is the genus Bifidobacterium Orla-Jensen 1924.

\section{Emended description of the family Bifidobacteriaceae Stackebrandt et al. 1997}

The family contains the type genus Bifidobacterium, as well as the genera Aeriscardovia Simpson et al. 2004, Alloscardovia Huys et al. 2007, Gardnerella Greenwood and Pickett 1980, Parascardovia Jian and Dong 2002 and Scardovia Jian and Dong 2002. The 16S rRNA nucleotide signature is as that of the order.

\section{Emended description of the order Actinomycetales Buchanan 1917, emend. Stackebrandt et al. 1997}

The pattern of 16S rRNA signatures consists of nucleotides at positions $688: 699(\mathrm{G}-\mathrm{C}), 701(\mathrm{C}), 823: 877(\mathrm{G}-\mathrm{C})$ and $1060: 1197$ (U-A). The order Actinomycetales contains the suborders Actinomycineae, Actinopolysporineae, Catenulisporineae, Corynebacterineae, Frankineae, Glycomycineae, Kineosporiineae, Micrococcineae, Micromonosporineae, Propionibacterineae, Pseudonocardineae, Streptomycineae and Streptosporangineae. The nomenclatural type is the genus Actinomyces Harz 1877.

\section{Emended description of the suborder Actinomycineae Stackebrandt et al. 1997}

The pattern of $16 \mathrm{~S}$ rRNA signatures consists of nucleotides at positions 127:234 (R-U), 598:640 (Y-G), $828(\mathrm{R})$, 829:857 (G-C), 832:854 (G-Y), 952:1229 (C-G) and 986:1219 (A-U). The suborder contains the family Actinomycetaceae. The nomenclatural type is the genus Actinomyces.

\section{Emended description of the family Actinomycetaceae Buchanan 1918, emend. Stackebrandt et al. 1997}

Genera belonging to the family are the type genus Actinomyces, as well as the genera Actinobaculum Lawson et al. 1997, Arcanobacterium Collins et al. 1983 (effective publication Collins et al., 1982), Mobiluncus Spiegel and Roberts 1984 and Varibaculum Hall et al. 2003. The 16S rRNA nucleotide signature is as that of the suborder.

\section{Description of the suborder Actinopolysporineae subord. nov.}

Actinopolysporineae (Ac.ti'no.po.ly.spo.ri'ne.ae. N.L. fem. $\mathrm{n}$. Actinopolyspora type genus of the suborder; -ineae ending to denote a suborder; N.L. fem. pl. n. Actinopolysporineae the Actinopolyspora suborder).

The pattern of 16S rRNA signatures consists of nucleotides at positions $127: 234(\mathrm{~A}-\mathrm{U}), 242: 284(\mathrm{C}-\mathrm{G}), 657: 749(\mathrm{G}-$ C), $672: 734(\mathrm{C}-\mathrm{G}), 828(\mathrm{~A}), 829: 857(\mathrm{G}-\mathrm{C}), 833: 853$ (UG), $840: 846$ (C-G), 986:1219 (U-A), 1100 (U), 1183 (C), 1117:1183 (G-C) and 1309:1328 (G-U). The suborder contains the family Actinopolysporaceae. The nomenclatural type is the genus Actinopolyspora Gochnauer et al. 1975. 


\section{Description of the family Actinopolysporaceae fam. nov.}

Actinopolysporaceae (Ac.ti'no.po.ly.spo.ra'ce.ae. N.L. fem. n. Actinopolyspora type genus of the family; -aceae ending to denote a family; N.L. fem. pl. n. Actinopolysporaceae the Actinopolyspora family).

The family contains the type genus Actinopolyspora. The $16 \mathrm{~S}$ rRNA nucleotide signature is as that of the suborder.

\section{Emended description of the suborder Catenulisporineae Cavaletti et al. 2006}

The pattern of $16 \mathrm{~S}$ rRNA signatures consists of nucleotides at positions $127: 234(\mathrm{G}-\mathrm{C}), 209(\mathrm{G}), 484(\mathrm{U}), 828(\mathrm{U}), 831: 855$ (G-G), 840:846 (U-G), 955: 1225 (C-G), 986:1219 (U-A) and 987:1218 (G-C). The suborder contains the families Catenulisporaceae and Actinospicaceae. The nomenclatural type is the genus Catenulispora Busti et al. 2006.

\section{Emended description of the family Catenulisporaceae Busti et al. 2006}

The pattern of 16S rRNA signatures consists of nucleotides at positions $262(\mathrm{~A}), 344(\mathrm{~A}), 576(\mathrm{~A}), 747$ (A), 129:232 (U-A), $580: 761(\mathrm{U}-\mathrm{A}), 658: 748(\mathrm{U}-\mathrm{U}), 659: 746(\mathrm{C}-\mathrm{G})$, $824: 876$ (A-U), 825:875 (A-U), 834:852 (G-G), 952: $1229(\mathrm{U}-\mathrm{A}), 986: 1219(\mathrm{U}-\mathrm{A})$ and 999:1041 (U-U).

The family contains the type genus Catenulispora.

\section{Emended description of the family Actinospicaceae Cavaletti et al. 2006}

The pattern of $16 \mathrm{~S}$ rRNA signatures consists of nucleotides at positions $262(\mathrm{G}), 344(\mathrm{G}), 576(\mathrm{G}), 747(\mathrm{U}), 129: 232$ (A-G), $580: 761(\mathrm{C}-\mathrm{G}), 586: 755(\mathrm{C}-\mathrm{G}), 658: 748(\mathrm{~A}-\mathrm{U})$, 659: 746 (U-A), $824: 876$ (C-G), $825: 875$ (G-C), $834: 852$ (G-C), 952:1229 (C-G), 986:1219(A-U) and 999:1041 (C-G). The family contains the type genus Actinospica Cavaletti et al. 2006.

\section{Emended description of the suborder Corynebacterineae Stackebrandt et al. 1997}

The pattern of $16 \mathrm{~S}$ rRNA signatures consists of nucleotides at positions 127:234 (G-Y), $564(\mathrm{C}), 672: 734(\mathrm{U}-\mathrm{G})$, 833:853 (U-G), 952:1229 (U-A) and 986:1219 (U-A). The suborder contains the families Corynebacteriaceae, Dietziaceae, Mycobacteriaceae, Nocardiaceae, Segniliparaceae and Tsukamurellaceae. The nomenclatural type is the genus Corynebacterium Lehmann and Neumann 1896.

\section{Emended description of the family Corynebacteriaceae Lehmann and Neumann 1907, emend. Stackebrandt et al. 1997}

The pattern of $16 \mathrm{~S}$ rRNA signatures consists of nucleotides at positions $250(\mathrm{U}), 316: 337(\mathrm{U}-\mathrm{G}), 418: 425(\mathrm{C}-\mathrm{G})$,
586:755 (U-G), 599:639 (C-G), 662:743 (U-G), 987:1218 (G-C) and 1059:1198 (U-A). The family contains the type genus Corynebacterium, as well as the genus Turicella Funke et al. 1994.

\section{Emended description of the family Dietziaceae Rainey et al. 1997}

The pattern of $16 \mathrm{~S}$ rRNA signatures consists of nucleotides at positions 241:285 (U-G), $250(\mathrm{U}), 316: 337(\mathrm{C}-\mathrm{G})$, $418: 425$ (U-A), 599:639 (C-G), 662:743 (C-G), 987:1218 (A-U), 1000:1040 (A-U), 1059:1198 (U-A) and $1115: 1185(\mathrm{C}-\mathrm{G})$. The family contains the type genus Dietzia Rainey et al. 1995.

\section{Emended description of the family Mycobacteriaceae Chester 1897, emend. Stackebrandt et al. 1997}

The pattern of $16 \mathrm{~S}$ rRNA signatures consists of nucleotides at positions 128:233 (G-C), $250(\mathrm{U}), 316: 337(\mathrm{C}-\mathrm{G})$, $418: 425 \quad(\mathrm{C}-\mathrm{G}), \quad 586: 755 \quad(\mathrm{U}-\mathrm{G}), \quad 599: 639 \quad(\mathrm{U}-\mathrm{G})$, $662: 743(\mathrm{C}-\mathrm{G}), 987: 1218(\mathrm{G}-\mathrm{C}), 1000: 1040(\mathrm{~A}-\mathrm{U})$ and 1026:1035 (U-G). The family contains the type genus Mycobacterium Lehmann and Neumann 1896.

\section{Emended description of the family Nocardiaceae Castellani and Chalmers 1919, emend. Rainey et al. 1997}

The pattern of 16S rRNA signatures consists of nucleotides at positions $250(\mathrm{U}), 316: 337(\mathrm{C}-\mathrm{G}), 418: 425(\mathrm{C}-\mathrm{G})$, 580:761 (U-A), 599:639 (C-G), $662: 743$ (C-G), 987: 1218 $(\mathrm{G}-\mathrm{C})$ and $1000: 1040(\mathrm{~A}-\mathrm{U})$. The family contains the type genus Nocardia Trevisan 1889, as well as the genera Gordonia (ex Tsukamura 1971) Stackebrandt et al. 1989 (effective publication Stackebrandt et al., 1988), Millisia Soddell et al. 2006, Rhodococcus Zopf 1891, Skermania Chun et al. 1997 and Williamsia Kämpfer et al. 1999.

\section{Emended description of the family Segniliparaceae Butler et al. 2005}

The pattern of $16 \mathrm{~S}$ rRNA signatures consists of nucleotides at positions 128:233 (G-C), 250 (A), 316:337 (C-G), 418: $425(\mathrm{C}-\mathrm{G}), 586: 755(\mathrm{C}-\mathrm{G}), 599: 639(\mathrm{C}-\mathrm{G}), 662: 743$ $(\mathrm{C}-\mathrm{G}), \quad 987: 1218 \quad(\mathrm{G}-\mathrm{C}), \quad 1000: 1040 \quad(\mathrm{~A}-\mathrm{G})$ and 1059:1198 (C-G). The family contains the type genus Segniliparus Butler et al. 2005.

\section{Emended description of the family Tsukamurellaceae Rainey et al. 1997}

The pattern of $16 \mathrm{~S}$ rRNA signatures consists of nucleotides at positions $128: 233(\mathrm{G}-\mathrm{C}), 250(\mathrm{U}), 316: 337(\mathrm{C}-\mathrm{G}), 418: 425$ (C-G), 580:761 (C-G), 599:639 (C-G), 987:1218 (G-C), 1000:1040 (A-C) and 1059:1198 (C-G). The family contains the type genus Tsukamurella Collins et al. 1988b. 


\section{Emended description of the suborder Frankineae Stackebrandt et al. 1997}

The pattern of $16 \mathrm{~S}$ rRNA signatures consists of nucleotides at positions $127: 234$ (G-C), $209(\mathrm{R}), 828(\mathrm{~A}), 833: 853$ (U-G), $840: 846$ (C-G), 844 (A), 845 (C), 1163:1173 (G-C), $1164: 1172(\mathrm{G}-\mathrm{U})$ and $1165: 1171(\mathrm{G}-\mathrm{C})$. The suborder contains the families Frankiaceae, Acidothermaceae, Cryptosporangiaceae, Geodermatophilaceae, Nakamurellaceae and Sporichthyaceae. The nomenclatural type is the genus Frankia Brunchorst 1886.

\section{Emended description of the family Frankiaceae Becking 1970, emend. Hahn et al. 1989, emend. Normand et al. 1996, emend. Stackebrandt et al. 1997}

The pattern of 16S rRNA signatures consists of nucleotides at positions 184:193 (A-C), 195 (A), 196 (U), $582: 758$ (U-A), 601 : 637 (G-U), $602: 636$ (C-G), 841 (C), $952: 1229$ (U-A), 986: 1219 (A-U), 1059: 1198 (C-G) and $1308: 1329$ (C-G). The family contains the type genus Frankia.

\section{Emended description of the family Acidothermaceae Rainey et al. 1997}

The pattern of $16 \mathrm{~S}$ rRNA signatures consists of nucleotides at positions 184: 193 (C-U), $195(\mathrm{G}), 196(\mathrm{C}), 203: 214$ (U-G), $589: 650$ (U-A), $601: 637$ (G-U), $602: 636$ (A-U), 614:626 (A-U), 841 (U), 952:1229 (U-A), 986:1219 (U-A), 1059:1198 (C-G) and 1308:1329 (C-G). The family contains the type genus Acidothermus Mohagheghi et al. 1986.

\section{Description of the family Cryptosporangiaceae fam. nov.}

Cryptosporangiaceae (Cryp'to.spo.ran.gi.a'ce.ae. N.L. neut. n. Cryptosporangium type genus of the family; -aceae ending to denote a family; N.L. fem. pl. n. Cryptosporangiaceae the Cryptosporangium family).

The pattern of 16S rRNA signatures consists of nucleotides at positions $195(\mathrm{U}), 196(\mathrm{C}), 601: 637(\mathrm{~A}-\mathrm{U}), 602: 636$ (C-G), 841 (U), 952:1229 (C-G), 986:1219 (A-U), 1042 (U), 1059: 1198 (U-A), 1251 (G) and 1003:1037 (A-C). The family contains the type genus Cryptosporangium Tamura et al. 1998.

\section{Emended description of the family Geodermatophilaceae Normand 2006}

The pattern of 16S rRNA signatures consists of nucleotides at positions $157: 164(\mathrm{~A}-\mathrm{U}), 158: 163(\mathrm{~A}-\mathrm{U}), 184: 193$ (AC), 195 (C), 196 (A), 293:304 (R-U), 601:637 (G-U), $602: 636$ (C-G), 841 (A), $952: 1229$ (U-A), $953: 1228$ (UA), 986:1219 (U-A), 1059:1198 (U-A) and 1027:1034 (C-G). The family contains the type genus Geodermatophilus Luedemann 1968, as well as the genera Blastococcus Ahrens and Moll 1970 and Modestobacter Mevs et al. 2000.

\section{Emended description of the family Nakamurellaceae Tao et al. 2004}

The pattern of 16S rRNA signatures consists of nucleotides at positions 184:193 (A-C), 195 (C), 196 (A), 589:650 (U-A), $601: 637$ (A-U), $602: 636$ (A-U), 670:736 (U-A), 841 (C), $952: 1229$ (C-G), $955: 1225$ (A-U), $986: 1219$ (AU), 1059: 1198 (U-A), 1120:1153 (U-A) and 1027:1034 (C-G). The family contains the type genus Nakamurella Tao et al. 2004, as well as the genera Humicoccus Yoon et al. 2007 and Saxeibacter Lee et al. 2008a.

\section{Emended description of the family Sporichthyaceae Rainey et al. 1997}

The pattern of 16S rRNA signatures consists of nucleotides at positions 184:193 (A-G), 195 (C), 196 (A), 416:427 (G-C), 600:638 (U-G), $601: 637$ (G-U), $602: 636$ (C-G), $612: 628$ (U-A), $841(\mathrm{U}), 952: 1229$ (U-A), $986: 1219$ (AU), 1042 (A) and 1059:1198 (U-A). The family contains the type genus Sporichthya Lechevalier et al. 1968.

\section{Emended description of the suborder Glycomycineae Rainey et al. 1997}

The pattern of 16S rRNA signatures consists of nucleotides at positions $657: 749(\mathrm{G}-\mathrm{U}), 672: 734(\mathrm{C}-\mathrm{G}), 681: 709(\mathrm{~A}-$ U), $831: 855$ (U-G), $832: 854$ (G-U), $833: 853$ (G-C), $840: 846$ (C-U), $952: 1229(\mathrm{C}-\mathrm{G}), 1064: 1192(\mathrm{G}-\mathrm{G})$ and 1117:1183 (A-U). The suborder contains the family Glycomycetaceae. The nomenclatural type is the genus Glycomyces Labeda et al. 1985.

\section{Emended description of the family Glycomycetaceae Rainey et al. 1997, emend. Labeda and Kroppenstedt 2005}

The family contains the type genus Glycomyces, as well as the genus Stackebrandtia Labeda and Kroppenstedt 2005. The $16 \mathrm{~S}$ rRNA nucleotide signature pattern is as that of the suborder.

\section{Description of the suborder Kineosporiineae subord. nov.}

Kineosporiineae (Ki'ne.o.spo.ri'i.ne.ae. N.L. fem. n. Kineosporia type genus of the suborder; -ineae ending to denote a suborder; N.L. fem. pl. n. Kineosporiineae the Kineosporia suborder).

The pattern of 16S rRNA signatures consists of nucleotides at positions $127: 234$ (A-U), $142: 221$ (C-U), $598: 640$ (U-G), $840: 846$ (A-C), 845 (A), 986:1218 (A-U), 1163:1173 (GU), $1164: 1172$ (G-C) and 1165:1171 (G-A). The suborder contains the family Kineosporiaceae. The nomenclatural type is the genus Kineosporia Pagani and Parenti 1978.

\section{Description of the family Kineosporiaceae fam. nov.}

Kineosporiaceae (Ki'ne.o.spo.ri.a'ce.ae. N.L. fem. n. Kineosporia type genus of the family; -aceae ending to denote a 
family; N.L. fem. pl. n. Kineosporiaceae the Kineosporia family).

The family contains the type genus Kineosporia, as well as the genera Kineococcus Yokota et al. 1993a and Quadrisphaera Maszenan et al. 2005. The 16S rRNA nucleotide signature pattern is as that of the suborder.

\section{Emended description of the suborder Micrococcineae Stackebrandt et al. 1997}

The pattern of 16S rRNA signatures consists of nucleotides at positions $127: 234(\mathrm{~A}-\mathrm{U}), 598: 640(\mathrm{U}-\mathrm{G}), 657: 749(\mathrm{U}-$ A), 953:1228 (G-C), 986:1219 (A-U), 987:1218 (A-U) and 1362 (A). The suborder contains the families Micrococcaceae, Dermatophilaceae, Beutenbergiaceae, Bogoriellaceae, Brevibacteriaceae, Cellulomonadaceae, Dermabacteraceae, Dermacoccaceae, Intrasporangiaceae, Jonesiaceae, Microbacteriaceae, Promicromonosporaceae, Rarobacteraceae, Sanguibacteraceae and Yaniellaceae. The nomenclatural type is the genus Micrococcus Cohn 1872. Patterns of $16 \mathrm{~S}$ rRNA signature nucleotides that define families of the suborder Micrococcineae are shown in Table 1.

\section{Emended description of the family Micrococcaceae Pribram 1929, emend. Stackebrandt et al. 1997}

The family contains the type genus Micrococcus, as well as the genera Acaricomes Pukall et al. 2006, Arthrobacter Conn and Dimmick 1947, emend. Koch et al. 1995, Citricoccus Altenburger et al. 2002b, Kocuria Stackebrandt et al. 1995, Nesterenkonia Stackebrandt et al. 1995, emend. Collins et al. 2002, emend. Li et al. 2005a, Renibacterium Sanders and Fryer 1980, Rothia Georg and Brown 1967 and Zhihengliuella Zhang et al. 2007a. The pattern of 16S rRNA signature nucleotides is shown in Table 1.

\section{Emended description of the family Dermatophilaceae Austwick 1958, emend. Stackebrandt et al. 1997, emend. Stackebrandt and Schumann 2000}

The family contains the type genus Dermatophilus (van Saceghem 1915) Gordon 1964, as well as the genus Kineosphaera Liu et al. 2002. The pattern of $16 \mathrm{~S}$ rRNA signature nucleotides is shown in Table 1.

\section{Description of the family Beutenbergiaceae fam. nov.}

Beutenbergiaceae (Beu'ten.ber.gi.a'ce.ae. N.L. fem. n. Beutenbergia type genus of the family; -aceae ending to denote a family; N.L. fem. pl. n. Beutenbergiaceae the Beutenbergia family).

The family contains the type genus Beutenbergia Groth et al. $1999 \mathrm{~b}$, as well as the genera Georgenia Altenburger et al. 2002a and Salana von Wintzingerode et al. 2001. The pattern of $16 \mathrm{~S}$ rRNA signature nucleotides is shown in Table 1.

\section{Emended description of the family Bogoriel- laceae Schumann and Stackebrandt 2000 (in Stackebrandt \& Schumann, 2000)}

The family contains the type genus Bogoriella Groth et al. 1997a. The pattern of 16S rRNA signature nucleotides is shown in Table 1.

\section{Emended description of the family Brevibacteriaceae Breed 1953, emend. Stackebrandt et al. 1997}

The family contains the type genus Brevibacterium Breed 1953, emend. Collins et al. 1980. The pattern of 16S rRNA signature nucleotides is shown in Table 1.

\section{Emended description of the family Cellulomonadaceae Stackebrandt and Prauser 1991, emend. Stackebrandt et al. 1997, emend. Stackebrandt and Schumann 2000}

The family contains the type genus Cellulomonas Bergey et al. 1923, emend. Clark 1952, emend. Stackebrandt et al. 1982, as well as the genera Actinotalea Yi et al. 2007, Demequina Yi et al. 2007, Oerskovia Prauser et al. 1970, emend. Lechevalier 1972, emend. Stackebrandt et al. 2002a and Tropheryma La Scola et al. 2001. The pattern of $16 \mathrm{~S}$ rRNA signature nucleotides is shown in Table 1.

\section{Emended description of the family Dermabacteraceae Stackebrandt et al. 1997}

The family contains the type genus Dermabacter Jones and Collins 1989 (effective publication Jones \& Collins, 1988), as well as the genus Brachybacterium Collins et al. 1988a. The pattern of $16 \mathrm{~S}$ rRNA signature nucleotides is shown in Table 1.

\section{Emended description of the family Dermacocc- aceae Schumann and Stackebrandt $\mathbf{2 0 0 0}$}

The family contains the type genus Dermacoccus Stackebrandt et al. 1995, as well as the genera Demetria Groth et al. 1997b and Kytococcus Stackebrandt et al. 1995. The pattern of $16 \mathrm{~S}$ rRNA signature nucleotides is shown in Table 1.

\section{Emended description of the family Intrasporangiaceae Rainey et al. 1997, emend. Stackebrandt and Schumann 2000}

The family contains the type genus Intrasporangium Kalakoutskii et al. 1967, as well as the genera Arsenicicoccus Collins et al. 2004, Humihabitans Kageyama et al. 2007, Janibacter Martin et al. 1997, Knoellia Groth et al. 2002, Kribbia Jung et al. 2006, Lapillicoccus Lee and Lee 
Table 1. Patterns of $16 \mathrm{~S}$ rRNA signature nucleotides that define families of the suborder Micrococcineae

Families: 1, Beutenbergiaceae; 2, Bogoriellaceae; 3, Brevibacteriaceae; 4, Cellulomonadaceae; 5, Dermabacteraceae; 6, Dermacoccaceae; 7, Dermatophilaceae; 8, Intrasporangiaceae; 9, Jonesiaceae; 10, Microbacteriaceae; 11, Micrococcaceae; 12, Promicromonosporaceae; 13, Rarobacteraceae; 14, Sanguibacteraceae; 15, Yaniellaceae. Residues in lower-case letters are present in some but not all strains.

\begin{tabular}{|c|c|c|c|c|c|c|c|c|c|c|c|c|c|c|c|}
\hline Position(s) & 1 & 2 & 3 & 4 & 5 & 6 & 7 & 8 & 9 & 10 & 11 & 12 & 13 & 14 & 15 \\
\hline 120 & A & A & A & A & A & A & A & A & A & A & $\mathrm{W}$ & A & A & A & $\mathrm{U}$ \\
\hline $131: 231$ & $C-G$ & $A-G$ & $C-G$ & C-G & $C-G$ & $A-G$ & $\mathrm{Y}-\mathrm{K}$ & $A-G$ & $A-G$ & G-R & $C-G$ & $A-G$ & $\mathrm{C}-\mathrm{G}$ & C-G & $A-G$ \\
\hline 196 & G & $\mathrm{U}$ & A & U & $\mathrm{U}$ & $\mathrm{C}$ & A & G & C & U & $\mathrm{C}$ & U & A & U & C \\
\hline $342: 347$ & $\mathrm{C}-\mathrm{G}$ & $\mathrm{U}-\mathrm{G}$ & $C-G$ & C-G & $C-G$ & $C-G$ & $C-G$ & $\mathrm{C}-\mathrm{G}$ & $C-G$ & $C-G$ & $C-G$ & $\mathrm{C}-\mathrm{G}$ & $\mathrm{C}-\mathrm{G}$ & C-G & $\mathrm{C}-\mathrm{G}$ \\
\hline $444: 490$ & $\mathrm{~A}-\mathrm{U}$ & $\mathrm{A}-\mathrm{U}$ & $\mathrm{A}-\mathrm{U}$ & $\mathrm{A}-\mathrm{U}$ & $\mathrm{A}-\mathrm{U}$ & $\mathrm{A}-\mathrm{U}$ & $\mathrm{A}-\mathrm{U}$ & $\mathrm{a}-\mathrm{u}$ & $\mathrm{A}-\mathrm{U}$ & $\mathrm{A}-\mathrm{U}$ & $\mathrm{A}-\mathrm{U}$ & $\mathrm{A}-\mathrm{U}$ & $\mathrm{A}-\mathrm{U}$ & $\mathrm{A}-\mathrm{U}$ & $\mathrm{U}-\mathrm{U}$ \\
\hline $580: 761$ & $C-G$ & C-A & $C-G$ & C-G & U-A & U-A & $\mathrm{U}-\mathrm{A}$ & U-A & $C-G$ & $C-G$ & $c-g$ & $\mathrm{C}-\mathrm{G}$ & $C-G$ & $C-G$ & $\mathrm{C}-\mathrm{G}$ \\
\hline $602: 636$ & $C-G$ & $C-G$ & $C-G$ & $c-g$ & $C-G$ & $C-G$ & $C-G$ & $C-G$ & $C-G$ & $C-G$ & $C-G$ & $\mathrm{G}-\mathrm{U}$ & $\mathrm{G}-\mathrm{U}$ & $\mathrm{G}-\mathrm{U}$ & $\mathrm{C}-\mathrm{G}$ \\
\hline $670: 736$ & $\mathrm{~A}-\mathrm{U}$ & $\mathrm{A}-\mathrm{U}$ & U-A & $\mathrm{A}-\mathrm{U}$ & $\mathrm{A}-\mathrm{U}$ & $\mathrm{A}-\mathrm{U}$ & $\mathrm{A}-\mathrm{U}$ & $\mathrm{A}-\mathrm{U}$ & $\mathrm{A}-\mathrm{U}$ & $\mathrm{A}-\mathrm{U}$ & $\mathrm{A}-\mathrm{U}$ & $\mathrm{A}-\mathrm{U}$ & $\mathrm{A}-\mathrm{U}$ & $\mathrm{A}-\mathrm{U}$ & $\mathrm{A}-\mathrm{U}$ \\
\hline $822: 878$ & $\mathrm{G}-\mathrm{C}$ & $\mathrm{G}-\mathrm{C}$ & $\mathrm{G}-\mathrm{C}$ & $\mathrm{G}-\mathrm{C}$ & $\mathrm{G}-\mathrm{C}$ & $\mathrm{G}-\mathrm{C}$ & $\mathrm{G}-\mathrm{C}$ & $\mathrm{G}-\mathrm{C}$ & $\mathrm{U}-\mathrm{C}$ & $\mathrm{G}-\mathrm{C}$ & $\mathrm{G}-\mathrm{C}$ & $\mathrm{G}-\mathrm{C}$ & $\mathrm{G}-\mathrm{C}$ & $\mathrm{G}-\mathrm{C}$ & $\mathrm{G}-\mathrm{C}$ \\
\hline $823: 877$ & $\mathrm{G}-\mathrm{C}$ & $\mathrm{G}-\mathrm{C}$ & $\mathrm{G}-\mathrm{C}$ & G-C & $\mathrm{G}-\mathrm{C}$ & $\mathrm{G}-\mathrm{C}$ & $\mathrm{G}-\mathrm{C}$ & $\mathrm{G}-\mathrm{C}$ & $\mathrm{A}-\mathrm{C}$ & $\mathrm{G}-\mathrm{C}$ & $\mathrm{G}-\mathrm{C}$ & $\mathrm{G}-\mathrm{C}$ & $\mathrm{G}-\mathrm{C}$ & $\mathrm{G}-\mathrm{C}$ & $\mathrm{G}-\mathrm{C}$ \\
\hline $826: 874$ & $\mathrm{C}-\mathrm{G}$ & $C-G$ & $C-G$ & $C-G$ & $C-G$ & $C-G$ & $C-G$ & $C-G$ & U-G & $C-G$ & $C-G$ & $\mathrm{C}-\mathrm{G}$ & $C-G$ & $\mathrm{C}-\mathrm{G}$ & $C-G$ \\
\hline 827 & U & U & U & U & U & U & U & U & G & U & U & U & U & U & $\mathrm{U}$ \\
\hline 843 & U & $\mathrm{C}$ & $\mathrm{C}$ & U & $\mathrm{C}$ & c & U & U & $\mathrm{C}$ & $\mathrm{C}$ & $\mathrm{C}$ & U & U & $\mathrm{C}$ & U \\
\hline $950: 1231$ & U-A & U-A & U-A & U-A & U-G & U-A & $\mathrm{U}-\mathrm{A}$ & U-A & U-A & U-A & U-A & $\mathrm{U}-\mathrm{A}$ & U-A & U-A & U-A \\
\hline $1047: 1210$ & $\mathrm{G}-\mathrm{C}$ & $\mathrm{G}-\mathrm{C}$ & $\mathrm{G}-\mathrm{U}$ & G-C & $\mathrm{G}-\mathrm{C}$ & $\mathrm{G}-\mathrm{C}$ & $\mathrm{G}-\mathrm{C}$ & $\mathrm{G}-\mathrm{C}$ & $\mathrm{G}-\mathrm{C}$ & $\mathrm{G}-\mathrm{C}$ & $\mathrm{G}-\mathrm{C}$ & $\mathrm{G}-\mathrm{C}$ & $\mathrm{G}-\mathrm{C}$ & $\mathrm{G}-\mathrm{C}$ & $\mathrm{G}-\mathrm{C}$ \\
\hline 1109 & C & C & C & C & C & C & C & C & C & C & C & C & C & C & G \\
\hline 1145 & G & G & A & G & G & G & G & G & G & $\mathrm{R}$ & G & G & G & G & G \\
\hline $1309: 1328$ & $\mathrm{G}-\mathrm{C}$ & $\mathrm{A}-\mathrm{U}$ & $\mathrm{G}-\mathrm{C}$ & G-C & $\mathrm{G}-\mathrm{U}$ & $\mathrm{G}-\mathrm{C}$ & $\mathrm{G}-\mathrm{C}$ & $\mathrm{G}-\mathrm{C}$ & $\mathrm{G}-\mathrm{C}$ & $\mathrm{G}-\mathrm{C}$ & $\mathrm{G}-\mathrm{C}$ & $\mathrm{G}-\mathrm{C}$ & $\mathrm{G}-\mathrm{C}$ & $\mathrm{G}-\mathrm{C}$ & $\mathrm{G}-\mathrm{C}$ \\
\hline 1361 & G & G & G & G & G & G & G & $\mathrm{C}$ & G & G & G & G & G & G & G \\
\hline 1383 & U & U & C & $\mathrm{Y}$ & C & C & C & C & C & C & C & C & C & C & C \\
\hline
\end{tabular}

2007, Marihabitans Kageyama et al. 2008, Ornithinicoccus Groth et al. 1999a, Ornithinimicrobium Groth et al. 2001, Oryzihumus Kageyama et al. 2005, Phycicoccus Lee 2006, Serinicoccus Yi et al. 2004, Terrabacter Collins et al. 1989, Terracoccus Prauser et al. 1997 and Tetrasphaera Maszenan et al. 2000. The pattern of $16 \mathrm{~S}$ rRNA signature nucleotides is shown in Table 1.

\section{Emended description of the family Jonesiaceae Stackebrandt et al. 1997}

The family contains the type genus Jonesia Rocourt and Stackebrandt 1987 (in Rocourt et al., 1987). The pattern of 16S rRNA signature nucleotides is shown in Table 1.

\section{Emended description of the family Microbacteri- aceae Park et al. 1995 (effective publication Park et al., 1993), emend. Rainey et al. 1997}

The family contains the type genus Microbacterium OrlaJensen 1919, emend. Takeuchi and Hatano 1998, as well as the genera Agreia Evtushenko et al. 2001, Agrococcus Groth et al. 1996, Agromyces Gledhill and Casida 1969, emend. Zgurskaya et al. 1992, Clavibacter Davis et al. 1984, Cryobacterium Suzuki et al. 1997, Curtobacterium Yamada and Komagata 1972, Frigoribacterium Kämpfer et al. 2000, Frondihabitans Greene et al. 2009 (previous illegitimate name Frondicola Zhang et al. 2007b), Glaciibacter Katayama et al. 2009, Gulosibacter Manaia et al. 2004, Klugiella Cook et al. 2008, Labedella Lee 2007, Leifsonia Evtushenko et al.
2000, Leucobacter Takeuchi et al. 1996, Microbacterium Orla-Jensen 1919, emend. Takeuchi and Hatano 1998, Microcella Tiago et al. 2005, emend. Tiago et al. 2006, Microterricola Matsumoto et al. 2008, Mycetocola Tsukamoto et al. 2001, Okibacterium Evtushenko et al. 2002, Plantibacter Behrendt et al. 2002, Phycicola Lee et al. 2008b, Pseudoclavibacter Manaia et al. 2004, Rathayibacter Zgurskaya et al. 1993, Rhodoglobus Sheridan et al. 2003, Salinibacterium Han et al. 2003, Subtercola Männistö et al. 2000 and Yonghaparkia Yoon et al. 2006. The pattern of $16 \mathrm{~S}$ rRNA signature nucleotides is shown in Table 1.

\section{Emended description of the family Promicromonosporaceae Rainey et al. 1997}

The family contains the type genus Promicromonospora Krasil'nikov et al. 1961, as well as the genera Cellulosimicrobium Schumann et al. 2001, emend Brown et al. 2006, Isoptericola Stackebrandt et al. 2004, Myceligenerans Cui et al. 2004, Xylanibacterium Rivas et al. 2004, Xylanimicrobium Stackebrandt and Schumann 2004 and Xylanimonas Rivas et al. 2003. The pattern of 16S rRNA signature nucleotides is shown in Table 1.

\section{Emended description of the family Rarobacter- aceae Stackebrandt and Schumann 2000}

The family contains the type genus Rarobacter Yamamoto et al. 1988. The pattern of $16 \mathrm{~S}$ rRNA signature nucleotides is shown in Table 1 . 


\section{Emended description of the family Sanguibacteraceae Stackebrandt and Schumann 2000}

The family contains the type genus Sanguibacter Fernández-Garayzábal et al. 1995. The pattern of $16 \mathrm{~S}$ rRNA signature nucleotides is shown in Table 1.

\section{Emended description of the family Yaniellaceae Li et al. 2008 (previous illegitimate name Yaniaceae Li et al. 2005b)}

The family contains the type genus Yaniella Li et al. 2008 (previous illegitimate name Yania Li et al. 2004, emend. Li et al. 2005b). The pattern of $16 \mathrm{~S}$ rRNA signature nucleotides is shown in Table 1.

\section{Emended description of the suborder Micromonosporineae Stackebrandt et al. 1997}

The pattern of $16 \mathrm{~S}$ rRNA signatures consists of nucleotides at positions 127:234 (A-U), $209(\mathrm{G}), 534(\mathrm{G}), 831: 855$ (U-G), 832:854 (G-Y), 833:853 (U-G), $840: 846$ (Y-G), $845(\mathrm{G}), 955: 1225(\mathrm{~A}-\mathrm{U}), 986: 1219(\mathrm{U}-\mathrm{A})$ and $987: 1218$ (G-C). The suborder contains the family Micromonosporaceae. The nomenclatural type is the genus Micromonospora Ørskov 1923.

\section{Emended description of the family Micromonosporaceae Krasil'nikov 1938, emend. Koch et al. 1996, emend. Stackebrandt et al. 1997}

The family contains the type genus Micromonospora, as well as Actinocatenispora Thawai et al. 2006, Actinoplanes Couch 1950, emend. Stackebrandt and Kroppenstedt 1987, Asanoa Lee and Hah 2002, Catellatospora Asano and Kawamoto 1986, Catenuloplanes Yokota et al. 1993b, Couchioplanes Tamura et al. 1994a, Dactylosporangium Thiemann et al. 1967b, Longispora Matsumoto et al. 2003, Pilimelia Kane 1966, Polymorphospora Tamura et al. 2006, Planosporangium Wiese et al. 2008, Pseudosporangium Ara et al. 2008, Salinispora Maldonado et al. 2005, Spirilliplanes Tamura et al. 1997, Verrucosispora Rheims et al. 1998 and Virgisporangium Tamura et al. 2001. The 16S rRNA nucleotide signature is as that of the suborder.

\section{Emended description of the suborder Propionibacterineae Rainey et al. 1997}

The pattern of 16S rRNA signatures consists of nucleotides at positions $127: 234(\mathrm{~A}-\mathrm{U}), 598: 640(\mathrm{U}-\mathrm{A}), 657: 749(\mathrm{G}-$ C), $828(\mathrm{U}), 829: 851$ (A-C), 832:854 (U-C), 833:853 $(\mathrm{G}-\mathrm{U}), 952: 1229(\mathrm{C}-\mathrm{G})$ and $986: 1219(\mathrm{U}-\mathrm{A})$. The suborder contains the families Propionibacteriaceae and Nocardioidaceae. The nomenclatural type is the genus Propionibacterium Orla-Jensen 1909.

\section{Emended description of the family Propionibacteriaceae Delwiche 1957, emend. Rainey et al. 1997}

The pattern of $16 \mathrm{~S}$ rRNA signatures consists of nucleotides at positions $328(\mathrm{U}), 407: 435(\mathrm{C}-\mathrm{G}), 451(\mathrm{~A}), 453(\mathrm{G}), 819$ (G), 825:875 (A-U), 827 (C), 828 (U), $832: 854$ (U-C), $833: 853$ (G-U) and 844 (U). The family contains the type genus Propionibacterium, as well as the genera Aestuariimicrobium Jung et al. 2007, Brooklawnia Rainey et al. 2006 (in Bae et al. 2006a), Friedmanniella Schumann et al. 1997, Granulicoccus Maszenan et al. 2007, Luteococcus Tamura et al. 1994b, Microlunatus Nakamura et al. 1995, Micropruina Shintani et al. 2000, Propionicicella Bae et al. 2006b, Propionicimonas Akasaka et al. 2003, Propioniferax Yokota et al. 1994, Propionimicrobium Stackebrandt et al. 2002b and Tessaracoccus Maszenan et al. 1999.

\section{Emended description of the family Nocardioidaceae Nesterenko et al. 1990 (effective publication Nesterenko et al., 1985), emend. Rainey et al. 1997}

The pattern of $16 \mathrm{~S}$ rRNA signatures consists of nucleotides at positions $328(\mathrm{C}), 407: 435(\mathrm{~A}-\mathrm{U}), 451(\mathrm{G}), 453(\mathrm{C}), 819$ (U), $825: 875(\mathrm{G}-\mathrm{C}), 827(\mathrm{U}), 828(\mathrm{~A}), 832: 854(\mathrm{G}-\mathrm{G})$, $833: 853$ (U-C) and 844 (C). The family contains the type genus Nocardioides Prauser 1976, as well as the genera Actinopolymorpha Wang et al. 2001, Aeromicrobium Miller et al. 1991, Jiangella Song et al. 2005, Kribbella Park et al. 1999 and Marmoricola Urzì et al. 2000.

\section{Emended description of the suborder Pseudonocardineae Stackebrandt et al. 1997}

The pattern of 16S rRNA signatures consists of nucleotides at positions $127: 234(\mathrm{G}-\mathrm{C}), 564(\mathrm{U}), 672: 734(\mathrm{U}-\mathrm{G})$, $831: 855$ (U-G), 832:854 (G-Y), 833:853 (U-G), 952:1229 (U-A) and 986:1219 (U-A). The suborder contains the families Pseudonocardiaceae and Actinosynnemataceae. The nomenclatural type is the genus Pseudonocardia Henssen 1957.

\section{Emended description of the family Pseudonocardiaceae Embley et al. 1989 (effective publication Embley et al., 1988), emend. Stackebrandt et al. 1997}

The pattern of 16S rRNA signatures consists of nucleotides at positions $211(\mathrm{G}), 480(\mathrm{U})$ and 142:221 (C-G). The family contains the type genus Pseudonocardia, as well as the genera Actinomycetospora Jiang et al. 2008, Allokutzneria Labeda and Kroppenstedt 2008, Amycolatopsis Lechevalier et al. 1986, Saccharopolyspora Lacey and Goodfellow 1975, Saccharomonospora Nonomura and Ohara 1971, Streptoalloteichus (ex Tomita et al. 1978) Tomita et al. 1987, Kibdelosporangium Shearer et al. 1986, Thermocrispum Korn-Wendisch et al. 1995, Kutzneria 
Stackebrandt et al. 1994, Actinoalloteichus Tamura et al. 2000b, Crossiella Labeda 2001, Prauserella Kim and Goodfellow 1999, emend. Li et al. 2003b and Goodfellowiella Labeda et al. 2008 (previous illegitimate name Goodfellowia Labeda and Kroppenstedt 2006).

\section{Emended description of the family Actino- synnemataceae Labeda and Kroppenstedt 2000}

The pattern of 16S rRNA signatures consists of nucleotides at positions 211 (A), $480(\mathrm{G})$ and 142:221 (C-C). The family contains the type genus Actinosynnema Hasegawa et al. 1978, as well as the genera Actinokineospora Hasegawa 1988, Lechevalieria Labeda et al. 2001, Lentzea Yassin et al. 1995, emend. Labeda et al. 2001, Saccharothrix Labeda et al. 1984 and Umezawaea Labeda and Kroppenstedt 2007.

\section{Emended description of the suborder Streptomycineae Rainey et al. 1997}

The pattern of $16 \mathrm{~S}$ rRNA signatures consists of nucleotides at positions 127:234 (G-C), 449 (A), 672:734 (C-G), 950: 1231 (U-G), 952 : 1229 (U-A), $955: 1225$ (C-G), 965 (C), $986: 1219$ (A-U) and 1362 (C). The suborder contains the family Streptomycetaceae. The nomenclatural type is the genus Streptomyces Waksman and Henrici 1943.

\section{Emended description of the family Streptomycetaceae Waksman and Henrici 1943, emend. Rainey et al. 1997, emend. Kim et al. 2003}

The family contains the type genus Streptomyces Waksman and Henrici 1943, emend. Witt and Stackebrandt 1990, emend. Wellington et al. 1992, as well as the genera Kitasatospora Ōmura et al. 1983 (effective publication Ōmura et al. 1982), emend. Zhang et al. 1997 and Streptacidiphilus Kim et al. 2003. The 16S rRNA nucleotide signature is as that of the suborder.

\section{Emended description of the suborder Streptosporangineae Ward-Rainey et al. 1997}

The pattern of 16S rRNA signatures consists of nucleotides at positions $127: 234(\mathrm{~A}-\mathrm{U}), 829: 857(\mathrm{G}-\mathrm{C}), 830: 856(\mathrm{G}-$ C), $953: 1228$ (U-A), $950: 1231$ (U-A), $955: 1225$ (C-G), 986:1219 (A-U) and 987:1218 (A-U). The suborder contains the families Streptosporangiaceae, Nocardiopsaceae and Thermomonosporaceae. The nomenclatural type is the genus Streptosporangium Couch 1955.

\section{Emended description of the family Strepto- sporangiaceae Goodfellow et al. 1990, emend. Ward-Rainey et al. 1997}

The pattern of 16S rRNA signatures consists of nucleotides at positions $440: 497$ (C-G), 485 (U), 501:544 (C-G), $502: 543$ (G-C), 833:853 (U-G) and 1355:1367 (A-U). The family contains the type genus Streptosporangium, as well as the genera Acrocarpospora Tamura et al. 2000a, Herbidospora Kudo et al. 1993, Microbispora Nonomura and Ohara 1957, Microtetraspora Thiemann et al. 1968, Nonomuraea Zhang et al. 1998, Planobispora Thiemann and Beretta 1968, Planomonospora Thiemann et al. 1967a, Planotetraspora Runmao et al. 1993, emend. Tamura and Sakane 2004 and Thermopolyspora (ex Krasil'nikov and Agre 1964) Goodfellow et al. 2005.

\section{Emended description of the family Nocardiop- saceae Rainey et al. 1996, emend. Rainey et al. 1997, emend. Zhang et al. 1998}

The pattern of 16S rRNA signatures consists of nucleotides at positions $440: 497$ (U-U), 485 (G), $501: 544$ (G-C), $502: 543$ (A-U), 833:853 (U-G) and 1355:1367 (G-C). The family contains the type genus Nocardiopsis (BrocqRousseau 1904) Meyer 1976, as well as the genera Haloactinospora Tang et al. 2008, Streptomonospora Cui et al. 2001, emend. Li et al. 2003a and Thermobifida Zhang et al. 1998.

\section{Emended description of the family Thermomono- sporaceae Rainey et al. 1997, emend. Zhang et al. 2001}

The pattern of $16 \mathrm{~S}$ rRNA signatures consists of nucleotides at positions $440: 497$ (C-G), $501: 544$ (C-G), $502: 543$ (G-C), 831 : 855 (G-G), $843(\mathrm{U}), 844$ (A) and 1355: 1367 (A-U). The family contains the type genus Thermomonospora Henssen 1957, as well as the genera Actinocorallia Iinuma et al. 1994, emend. Zhang et al. 2001, Actinomadura Lechevalier and Lechevalier 1968 (effective publication Lechevalier \& Lechevalier, 1970) and Spirillospora Couch 1963.

\section{Note added on revision}

Since this article was submitted for publication, an additional order of the subclass Actinobacteridae has been described, Nitriliruptorales Sorokin et al. 2009, to accommodate a new family Nitriliruptoraceae and the new genus and species Nitriliruptor alkaliphilus.

\section{ACKNOWLEDGEMENTS}

The authors are grateful to Dr Jean Euzéby for support with nomenclature. This research was supported by the National Basic Research Program of China (no. 2004CB719601), the National Natural Science Foundation of China (nos 30600001 and 30870005) and the Key Project of Chinese Ministry of Education (no. 206139). W.-J.L. was supported by the Program for New Century Excellent Talents in University.

\section{REFERENCES}

Ahrens, R. \& Moll, G. (1970). Ein neues knospendes Bakterium aus der Ostsee. Arch Mikrobiol 70, 243-265 (in German).

Akasaka, H., Ueki, A., Hanada, S., Kamagata, Y. \& Ueki, K. (2003). Propionicimonas paludicola gen. nov., sp. nov., a novel facultatively 
anaerobic, Gram-positive, propionate-producing bacterium isolated from plant residue in irrigated rice-field soil. Int J Syst Evol Microbiol 53, 1991-1998.

Altenburger, P., Kämpfer, P., Schumann, P., Vybiral, D., Lubitz, W. \& Busse, H. J. (2002a). Georgenia muralis gen. nov., sp. nov., a novel actinobacterium isolated from a medieval wall painting. Int $J$ Syst Evol Microbiol 52, 875-881.

Altenburger, P., Kämpfer, P., Schumann, P., Steiner, R., Lubitz, W. \& Busse, H. J. (2002b). Citricoccus muralis gen. nov., sp. nov., a novel actinobacterium isolated from a medieval wall painting. Int J Syst Evol Microbiol 52, 2095-2100.

Anderson, R. C., Rasmussen, M. A., Jensen, N. S. \& Allison, M. J. (2000). Denitrobacterium detoxificans gen. nov., sp. nov., a ruminal bacterium that respires on nitrocompounds. Int J Syst Evol Microbiol 50, 633-638.

Ara, I., Matsumoto, A., Bakir, M. A., Kudo, T., Ōmura, S. \& Takahashi, Y. (2008). Pseudosporangium ferrugineum gen. nov., sp. nov., a new member of the family Micromonosporaceae. Int J Syst Evol Microbiol 58, 1644-1652.

Asano, K. \& Kawamoto, I. (1986). Catellatospora, a new genus of Actinomycetales. Int J Syst Bacteriol 36, 512-517.

Austwick, P. K. C. (1958). Cutaneous streptothrichosis mycotic dermatitis and strawberry foot rot and the genus Dermatophilus van Saceghem. Vet Rev Annot 4, 33-48.

Bae, H. S., Moe, W. M., Yan, J., Tiago, I., da Costa, M. S. \& Rainey, F. A. (2006a). Brooklawnia cerclae gen. nov., sp. nov., a propionate-forming bacterium isolated from chlorosolvent-contaminated groundwater. Int J Syst Evol Microbiol 56, 1977-1983.

Bae, H. S., Moe, W. M., Yan, J., Tiago, I., da Costa, M. S. \& Rainey, F. A. (2006b). Propionicicella superfundia gen. nov., sp. nov., a chlorosolvent-tolerant propionate-forming, facultative anaerobic bacterium isolated from contaminated groundwater. Syst Appl Microbiol 29, 404-413.

Becking, J. H. (1970). Frankiaceae fam. nov. (Actinomycetales) with one new combination and six new species of the genus Frankia Brunchorst 1887, 174. Int J Syst Bacteriol 20, 201-220.

Behrendt, U., Ulrich, A., Schumann, P., Naumann, D. \& Suzuki, K. (2002). Diversity of grass-associated Microbacteriaceae isolated from the phyllosphere and litter layer after mulching the sward; a polyphasic characterization of Subtercola pratensis sp. nov., Curtobacterium herbarum sp. nov. and Plantibacter flavus gen. nov., sp. nov. Int J Syst Evol Microbiol 52, 1441-1454.

Bergey, D. H., Harrison, F. C., Breed, R. S., Hammer, B. W. \& Huntoon, F. M. (1923). Bergey's Manual of Determinative Bacteriology. Baltimore: Williams \& Wilkins.

Breed, R. S. (1953). The families developed from Bacteriaceae Cohn with a description of the family Brevibacteriaceae Breed, 1953. VI Congr Int Microbiol Roma 1, 10-15.

Brosius, J., Palmer, M. L., Kennedy, J. P. \& Noller, H. P. (1978). Complete nucleotide sequence of a $16 \mathrm{~S}$ ribosomal RNA gene from Escherichia coli. Proc Natl Acad Sci U S A 75, 4801-4805.

Brown, J. M., Steigerwalt, A. G., Morey, R. E., Daneshvar, M. I., Romero, L. J. \& McNeil, M. M. (2006). Characterization of clinical isolates previously identified as Oerskovia turbata, proposal of Cellulosimicrobium funkei sp. nov. and emended description of the genus Cellulosimicrobium. Int J Syst Evol Microbiol 56, 801-804.

Brunchorst, J. (1886). Über einige Wurzelanschwellungen besonders diejenigen von Alnus und den Elaeagnaceen. Bot Inst Tübingen 2, 151-177 (in German).

Buchanan, R. E. (1917). Studies in the nomenclature and classification of the bacteria. II. The primary subdivisions of the schizomycetes. J Bacteriol 2, 155-164.
Buchanan, R. E. (1918). Studies in the nomenclature and classification of the bacteria. VIII. The subgroups and genera of the Actinomycetales. J Bacteriol 3, 403-406.

Busti, E., Cavaletti, L., Monciardini, P., Schumann, P., Rohde, M., Sosio, M. \& Donadio, S. (2006). Catenulispora acidiphila gen. nov., sp. nov., a novel, mycelium-forming actinomycete, and proposal of Catenulisporaceae fam. nov. Int J Syst Evol Microbiol 56, 1741-1746.

Butler, W. R., Floyd, M. M., Brown, J. M., Toney, S. R., Daneshvar, M. I., Cooksey, R. C., Steigerwalt, A. G. \& Charles, N. (2005). Novel mycolic acid-containing bacteria in the family Segniliparaceae fam. nov., including the genus Segniliparus gen. nov., with descriptions of Segniliparus rotundus sp. nov. and Segniliparus rugosus sp. nov. Int J Syst Evol Microbiol 55, 1615-1624.

Castellani, A. \& Chalmers, A. J. (1919). Manual of Tropical Medicine, 3rd edn. New York: Williams Wood and Co.

Cavaletti, L., Monciardini, P., Schumann, P., Rohde, M., Bamonte, R., Busti, E., Sosio, M. \& Donadio, S. (2006). Actinospica robiniae gen. nov., sp. nov. and Actinospica acidiphila sp. nov., proposal for Actinospicaceae fam. nov. and Catenulisporinae subord. nov. in the order Actinomycetales. Int J Syst Evol Microbiol 56, 1747-1753.

Chester, F. D. (1897). Report of the mycologist; bacteriological work. Del Agric Exp Stn Bull 9, 38-145.

Chun, J., Blackall, L. L., Kang, S. O., Hah, Y. C. \& Goodfellow, M. (1997). A proposal to reclassify Nocardia pinensis Blackall et al. as Skermania piniformis gen. nov., comb. nov. Int J Syst Bacteriol 47, 127-131.

Clark, F. E. (1952). The generic classification of the soil corynebacteria. Int Bull Bacteriol Nomencl Taxon 2, 45-56.

Clark, D. A. \& Norris, P. R. (1996). Acidimicrobium ferrooxidans gen. nov., sp. nov., mixed-culture ferrous iron oxidation with Sulfobacillus species. Microbiology 142, 785-790.

Cohn, F. (1872). Untersuchungen über Bakterien. Beitr Biol Pflanz 1, 127-224 (in German).

Cole, J. R., Chai, B., Farris, R. J., Wang, Q., Kulam-Syed-Mohideen, A. S., McGarrell, D. M., Bandela, A. M., Cardenas, E., Garrity, G. M. \& Tiedje, J. M. (2007). The ribosomal database project (RDP-II), introducing myRDP space and quality controlled public data. Nucleic Acids Res 35, D169-D172.

Collins, M. D. \& Wallbanks, S. (1992). Comparative sequence analyses of the 16S rRNA genes of Lactobacillus minutus, Lactobacillus rimae and Streptococcus parvulus: proposal for the creation of a new genus Atopobium. FEMS Microbiol Lett 74, 235-240.

Collins, M. D., Jones, D., Keddie, R. M. \& Sneath, P. H. A. (1980). Reclassification of Chromobacterium iodinum (Davis) in a redefined genus Brevibacterium (Breed) as Brevibacterium iodinum nom. rev.; comb. nov. J Gen Microbiol 120, 1-10.

Collins, M. D., Jones, D. \& Schofield, G. M. (1982). Reclassification of 'Corynebacterium haemolyticum' (Mac Lean, Liebow and Rosenberg) in the genus Arcanobacterium gen. nov. as Arcanobacterium haemolyticum nom. rev., comb. nov. J Gen Microbiol 128, 1279-1281.

Collins, M. D., Brown, J. \& Jones, D. (1988a). Brachybacterium faecium gen. nov., sp. nov., a coryneform bacterium from poultry deep litter. Int J Syst Bacteriol 38, 45-48.

Collins, M. D., Smida, J., Dorsch, M. \& Stackebrandt, E. (1988b). Tsukamurella gen. nov., harboring Corynebacterium paurometabolum and Rhodococcus aurantiacus. Int J Syst Bacteriol 38, 385-391.

Collins, M. D., Dorsch, M. \& Stackebrandt, E. (1989). Transfer of Pimelobacter tumescens to Terrabacter gen. nov. as Terrabacter tumescens comb. nov. and of Pimelobacter jensenii to Nocardioides as Nocardioides jensenii comb. nov. Int J Syst Bacteriol 39, 1-6. 
Collins, M. D., Lawson, P. A., Labrenz, M., Tindall, B. J., Weiss, N. \& Hirsch, P. (2002). Nesterenkonia lacusekhoensis sp. nov., isolated from hypersaline Ekho Lake, East Antarctica, and emended description of the genus Nesterenkonia. Int J Syst Evol Microbiol 52, 1145-1150.

Collins, M. D., Routh, J., Saraswathy, A., Lawson, P. A., Schumann, P., Welinder-Olsson, C. \& Falsen, E. (2004). Arsenicicoccus bolidensis gen. nov., sp. nov., a novel actinomycete isolated from contaminated lake sediment. Int J Syst Evol Microbiol 54, 605-608.

Conn, H. J. \& Dimmick, I. (1947). Soil bacteria similar in morphology to Mycobacterium and Corynebacterium. J Bacteriol 54, 291-303.

Cook, D. M., Decrescenzo Henriksen, E., Rogers, T. E. \& Peterson, J. D. (2008). Klugiella xanthotipulae gen. nov., sp. nov., a novel member of the family Microbacteriaceae. Int J Syst Evol Microbiol 58, 2779-2782.

Couch, J. N. (1950). Actinoplanes a new genus of the Actinomycetales. J Elisha Mitchell Sci Soc 66, 87-92.

Couch, J. N. (1955). A new genus and family of the Actinomycetales, with a revision of the genus Actinoplanes. J Elisha Mitchell Sci Soc 71, 148-155.

Couch, J. N. (1963). Some new genera and species of the Actinoplanaceae. J Elisha Mitchell Sci Soc 79, 53-70.

Cui, X.-L., Mao, P.-H., Zeng, M., Li, W.-J., Zhang, L.-P., Xu, L.-H. \& Jiang, C.-L. (2001). Streptimonospora salina gen. nov., sp. nov., a new member of the family Nocardiopsaceae. Int J Syst Evol Microbiol 51, 357-363.

Cui, X.-L., Schumann, P., Stackebrandt, E., Kroppenstedt, R. M., Pukall, R., Xu, L.-H., Rohde, M. \& Jiang, C.-L. (2004). Myceligenerans xiligouense gen. nov., sp. nov., a novel hyphae-forming member of the family Promicromonosporaceae. Int J Syst Evol Microbiol 54, 1287-1293.

Davis, M. J., Gillaspsie, A. G., Jr, Vidaver, A. K. \& Harris, R. W. (1984). Clavibacter, a new genus containing some phytopathogenic coryneform bacteria, including Clavibacter xyli subsp. xyli sp. nov., subsp. nov. and Clavibacter xyli subsp. cynodontis subsp. nov., pathogens that cause ratoon stunting disease of sugarcane and Bermudagrass stunting disease. Int J Syst Bacteriol 34, 107-117.

Delwiche, E. A. (1957). Family XI. Propionibacteriaceae fam. nov. In Bergey's Manual of Determinative Bacteriology, 7th edn, p. 569. Edited by R. S. Breed, E. G. D. Murray \& N. R. Smith. London: Ballière, Tindall \& Cox.

Dewhirst, F. E., Paster, B. J., Tzellas, N., Coleman, B., Downes, J., Spratt, D. A. \& Wade, W. G. (2001). Characterization of novel human oral isolates and cloned $16 \mathrm{~S}$ rDNA sequences that fall in the family Coriobacteriaceae, description of Olsenella gen. nov., reclassification of Lactobacillus uli as Olsenella uli comb. nov., and description of Olsenella profusa sp. nov. Int J Syst Evol Microbiol 51, 1797-1804.

Embley, M. T., Smida, J. \& Stackebrandt, E. (1988). The phylogeny of mycolate-less wall chemotype IV actinomycetes and description of Pseudonocardiaceae fam. nov. Syst Appl Microbiol 11, 44-52.

Evtushenko, L. I., Dorofeeva, L. V., Subbotin, S. A., Cole, J. R. \& Tiedje, J. M. (2000). Leifsonia poae gen. nov., sp. nov., isolated from nematode galls on Poa annua, and reclassification of 'Corynebacterium aquaticum' Leifson 1962 as Leifsonia aquatica (ex Leifson 1962) gen. nov., nom. rev., comb. nov. and Clavibacter xyli Davis et al. 1984 with two subspecies as Leifsonia xyli (Davis et al. 1984) gen. nov., comb. nov. Int J Syst Evol Microbiol 50, 371-380.

Evtushenko, L. I., Dorofeeva, L. V., Dobrovolskaya, T. G., Streshinskaya, G. M., Subbotin, S. A. \& Tiedje, J. M. (2001). Agreia bicolorata gen. nov., sp. nov., to accommodate actinobacteria isolated from narrow reed grass infected by the nematode Heteroanguina graminophila. Int J Syst Evol Microbiol 51, 2073-2079.

Evtushenko, L. I., Dorofeeva, L. V., Krausova, V. I., Gavrish, E. Y., Yashina, S. G. \& Takeuchi, M. (2002). Okibacterium fritillariae gen. nov., sp. nov., a novel genus of the family Microbacteriaceae. Int $J$ Syst Evol Microbiol 52, 987-993.

Farris, J. S., Kallersjö, M., Kluge, A. G. \& Bult, C. (1995). Constructing a significance test for incongruence. Syst Biol 44, 570-572.

Felsenstein, J. (1985). Confidence limits on phylogenies, an approach using the bootstrap. Evolution 39, 783-791.

Felsenstein, J. (2005). PHYLIP (phylogeny inference package), version 3.65. Distributed by the author. Department of Genome Sciences, University of Washington, Seattle, USA.

Fernández-Garayzábal, J. F., Dominguez, L., Pascual, C., Jones, D. \& Collins, M. D. (1995). Phenotypic and phylogenetic characterization of some unknown coryneform bacteria isolated from bovine blood and milk: description of Sanguibacter gen. nov. Lett Appl Microbiol 20, 69-75.

Funke, G., Stubbs, S., Altwegg, M., Carlotti, A. \& Collins, M. D. (1994). Turicella otitidis gen. nov., sp. nov., a coryneform bacterium isolated from patients with otitis media. Int J Syst Bacteriol 44, 270-273.

Gao, B. \& Gupta, R. S. (2005). Conserved indels in protein sequences that are characteristic of the phylum Actinobacteria. Int J Syst Evol Microbiol 55, 2401-2412.

Gao, B., Paramanathan, R. \& Gupta, R. S. (2006). Signature proteins that are distinctive characteristics of Actinobacteria and their subgroups. Antonie van Leeuwenhoek 90, 69-91.

Georg, L. K. \& Brown, J. M. (1967). Rothia gen. nov., an aerobic genus of the family Actinomycetaceae. Int J Syst Bacteriol 17, 79-88.

Gledhill, W. E. \& Casida, L. E. (1969). Predominant catalase-negative soil bacteria. III. Agromyces gen. n., microorganisms intermediary to Actinomyces and Nocardia. Appl Microbiol 18, 340-349.

Gochnauer, M. B., Leppard, G. G., Komaratat, P., Kates, M., Novitsky, T. \& Kushner, D. J. (1975). Isolation and characterization of Actinopolyspora halophila, gen. et sp. nov., an extremely halophilic actinomycete. Can J Microbiol 21, 1500-1511.

Goodfellow, M., Stanton, L. J., Simpson, K. E. \& Minnikin, D. E. (1990). Numerical and chemical classification of Actinoplanes and some related actinomycetes. J Gen Microbiol 136, 19-36.

Goodfellow, M., Maldonado, L. A. \& Quintana, E. T. (2005). Reclassification of Nonomuraea flexuosa (Meyer 1989) Zhang et al. 1998 as Thermopolyspora flexuosa gen. nov., comb. nov., nom. rev. Int J Syst Evol Microbiol 55, 1979-1983.

Gordon, M. A. (1964). The genus Dermatophilus. J Bacteriol 88, 509-522. Greene, A. C., Euzéby, J. P., Tindall, B. J. \& Patel, B. K. C. (2009). Proposal of Frondihabitans gen. nov. to replace the illegitimate genus name Frondicola Zhang et al. 2007. Int J Syst Evol Microbiol 59, 447-448.

Greenwood, J. R. \& Pickett, M. J. (1980). Transfer of Haemophilus vaginalis Gardner and Dukes to a new genus, Gardnerella: G. vaginalis (Gardner and Dukes) comb. nov. Int J Syst Bacteriol 30, 170-178.

Groth, I., Schumann, P., Weiss, N., Martin, K. \& Rainey, F. A. (1996). Agrococcus jenensis gen. nov., sp. nov., a new genus of actinomycetes with diaminobutyric acid in the cell wall. Int J Syst Bacteriol 46, 234-239.

Groth, I., Schumann, P., Rainey, F. A., Martin, K., Schuetze, B. \& Augsten, K. (1997a). Bogoriella caseilytica gen. nov., sp. nov., a new alkaliphilic actinomycete from a soda lake in Africa. Int J Syst Bacteriol 47, 788-794.

Groth, I., Schumann, P., Rainey, F. A., Martin, K., Schuetze, B. \& Augsten, K. (1997b). Demetria terragena gen. nov., sp. nov., a new genus of actinomycetes isolated from compost soil. Int J Syst Bacteriol 47, 1129-1133.

Groth, I., Schumann, P., Martin, K., Schuetze, B., Augsten, K., Kramer, I. \& Stackebrandt, E. (1999a). Ornithinicoccus hortensis gen. nov., sp. nov., a soil actinomycete which contains L-ornithine. Int $J$ Syst Bacteriol 49, 1717-1724. 
Groth, I., Schumann, P., Schuetze, B., Augsten, K., Kramer, I. \& Stackebrandt, E. (1999b). Beutenbergia cavernae gen. nov., sp. nov., an L-lysine-containing actinomycete isolated from a cave. Int J Syst Bacteriol 49, 1733-1740.

Groth, I., Schumann, P., Weiss, N., Schuetze, B., Augsten, K. \& Stackebrandt, E. (2001). Ornithinimicrobium humiphilum gen. nov., sp. nov., a novel soil actinomycete with L-ornithine in the peptidoglycan. Int J Syst Evol Microbiol 51, 81-87.

Groth, I., Schumann, P., Schuetze, B., Augsten, K. \& Stackebrandt, E. (2002). Knoellia sinensis gen. nov., sp. nov. and Knoellia subterranea sp. nov., two novel actinobacteria isolated from a cave. Int J Syst Evol Microbiol 52, 77-84.

Haas, F. \& König, H. (1988). Coriobacterium glomerans gen. nov., sp. nov. from the intestinal tract of the red soldier bug. Int J Syst Bacteriol 38, 382-384.

Hahn, D., Lechevalier, M. P., Fischer, A. \& Stackebrandt, E. (1989). Evidence for a close phylogenetic relationship between members of the genera Frankia, Geodermatophilus and Blastococcus and emendation of the family Frankiaceae. Syst Appl Microbiol 11, 236-242.

Hall, T. A. (1999). BioEdit, a user-friendly biological sequence alignment editor and analysis program for Windows 95/98/NT. Nucleic Acids Symp Ser 41, 95-98.

Hall, V., Collins, M. D., Lawson, P. A., Hutson, R. A., Falsen, E., Inganas, E. \& Duerden, B. (2003). Characterization of some Actinomyces-like isolates from human clinical sources: description of Varibaculum cambriensis gen. nov., sp. nov. J Clin Microbiol 41, 640-644.

Han, S. K., Nedashkovskaya, O. I., Mikhailov, V. V., Kim, S. B. \& Bae, K. S. (2003). Salinibacterium amurskyense gen. nov., sp. nov., a novel genus of the family Microbacteriaceae from the marine environment. Int J Syst Evol Microbiol 53, 2061-2066.

Harz, C. O. (1877). Actinomyces bovis, ein neuer Schimmel in den Geweben des Rindes. Dtsch Z Thiermedizin 5, 125-140 (in German).

Hasegawa, T. (1988). Actinokineospora, a new genus of the Actinomycetales. Actinomycetologica 2, 31-45.

Hasegawa, T., Lechevalier, M. P. \& Lechevalier, H. A. (1978). A new genus of the Actinomycetales, Actinosynnema gen. nov. Int J Syst Bacteriol 28, 304-310.

Henssen, A. (1957). Beiträge zur Morphologie und Systematik der thermophilen Actinomyceten. Arch Mikrobiol 26, 373-414 (in German).

Hugenholtz, P. \& Stackebrandt, E. (2004). Reclassification of Sphaerobacter thermophilus from the subclass Sphaerobacteridae in the phylum Actinobacteria to the class Thermomicrobia (emended description) in the phylum Chloroflexi (emended description). Int J Syst Evol Microbiol 54, 2049-2051.

Huys, G., Vancanneyt, M., D’Haene, K., Falsen, E., Wauters, G. \& Vandamme, P. (2007). Alloscardovia omnicolens gen. nov., sp. nov., from human clinical samples. Int J Syst Evol Microbiol 57, 1442-1446.

linuma, S., Yokota, A., Hasegawa, T. \& Kanamaru, T. (1994). Actinocorallia gen. nov., a new genus of the order Actinomycetales. Int J Syst Bacteriol 44, 230-234.

Jian, W. \& Dong, X. (2002). Transfer of Bifidobacterium inopinatum and Bifidobacterium denticolens to Scardovia inopinata gen. nov., comb. nov., and Parascardovia denticolens gen. nov., comb. nov., respectively. Int J Syst Evol Microbiol 52, 809-812.

Jiang, Y., Wiese, J., Tang, S.-K., Xu, L.-H., Imhoff, J. F. \& Jiang, C.-L. (2008). Actinomycetospora chiangmaiensis gen. nov., sp. nov., a new member of the family Pseudonocardiaceae. Int J Syst Evol Microbiol 58, 408-413.

Jones, D. \& Collins, M. D. (1988). Taxonomic studies on some human cutaneous coryneform bacteria: description of Dermabacter hominis gen. nov., sp. nov. FEMS Microbiol Lett 51, 51-55.
Jung, S. Y., Kim, H. S., Song, J. J., Lee, S. G., Oh, T. K. \& Yoon, J. H. (2006). Kribbia dieselivorans gen. nov., sp. nov., a novel member of the family Intrasporangiaceae. Int J Syst Evol Microbiol 56, 2427-2432.

Jung, S.-Y., Kim, H.-S., Song, J.-J., Lee, S.-G., Oh, K.-T. \& Yoon, J.-H. (2007). Aestuariimicrobium kwangyangense gen. nov., sp. nov., an LLdiaminopimelic acid-containing bacterium isolated from tidal flat sediment. Int J Syst Evol Microbiol 57, 2114-2118.

Kageyama, A. \& Benno, Y. (2000). Emendation of genus Collinsella and proposal of Collinsella stercoris sp. nov. and Collinsella intestinalis sp. nov. Int J Syst Evol Microbiol 50, 1767-1774.

Kageyama, A., Benno, Y. \& Nakase, T. (1999). Phylogenetic and phenotypic evidence for the transfer of Eubacterium aerofaciens to the genus Collinsella as Collinsella aerofaciens gen. nov., comb. nov. Int J Syst Bacteriol 49, 557-565.

Kageyama, A., Takahashi, Y., Seki, T., Tomoda, H. \& Ōmura, S. (2005). Oryzihumus leptocrescens gen. nov., sp. nov. Int J Syst Evol Microbiol 55, 2555-2559.

Kageyama, A., Takahashi, Y. \& Ōmura, S. (2007). Humihabitans oryzae gen. nov., sp. nov. Int J Syst Evol Microbiol 57, 2163-2166.

Kageyama, A., Haga, T., Kasai, H., Shizuri, Y., Ōmura, S. \& Takahashi, Y. (2008). Marihabitans asiaticum gen. nov., sp. nov., a meso-diaminopimelic acid-containing member of the family Intrasporangiaceae. Int J Syst Evol Microbiol 58, 2429-2432.

Kalakoutskii, L. V., Kirillova, I. P. \& Krasil'nikov, N. A. (1967). A new genus of the Actinomycetales - Intrasporangium gen. nov. J Gen Microbiol 48, 79-85.

Kämpfer, P., Andersson, M. A., Rainey, F. A., Kroppenstedt, R. M. \& Salkinoja-Salonen, M. (1999). Williamsia muralis gen. nov., sp. nov., isolated from the indoor environment of a children's day care centre. Int J Syst Bacteriol 49, 681-687.

Kämpfer, P., Rainey, F. A., Andersson, M. A., Nurmiaho Lassila, E. L., Ulrych, U., Busse, H.-J., Weiss, N., Mikkola, R. \& Salkinoja-Salonen, M. (2000). Frigoribacterium faeni gen. nov., sp. nov., a novel psychrophilic genus of the family Microbacteriaceae. Int J Syst Evol Microbiol 50, 355-363.

Kane, W. D. (1966). A new genus of Actinoplanaceae, Pilimelia, with a description of two species, Pilimelia terevasa and Pilimelia anulata. J Elisha Mitchell Sci Soc 82, 220-230.

Katayama, T., Kato, T., Tanaka, M., Douglas, T. A., Brouchkov, A., Fukuda, M., Tomita, F. \& Asano, K. (2009). Glaciibacter superstes gen. nov., sp. nov., a novel member of the family Microbacteriaceae isolated from a permafrost ice wedge. Int J Syst Evol Microbiol 59, 482-486.

Kim, S.-B. \& Goodfellow, M. (1999). Reclassification of Amycolatopsis rugosa Lechevalier et al. 1986 as Prauserella rugosa gen. nov., comb. nov. Int J Syst Bacteriol 49, 507-512.

Kim, S. B., Lonsdale, J., Seong, C.-N. \& Goodfellow, M. (2003). Streptacidiphilus gen. nov., acidophilic actinomycetes with wall chemotype I and emendation of the family Streptomycetaceae (Waksman and Henrici $(1943)^{\mathrm{AL}}$ ) emend. Rainey et al. 1997. Antonie van Leeuwenhoek 83, 107-116.

Kimura, M. (1980). A simple method for estimating evolutionary rates of base substitutions through comparative studies of nucleotide sequences. J Mol Evol 16, 111-120.

Koch, C., Schumann, P. \& Stackebrandt, E. (1995). Reclassification of Micrococcus agilis Ali-Cohen 1889 to the genus Arthrobacter as Arthrobacter agilis comb. nov. and emendation of the genus Arthrobacter. Int J Syst Bacteriol 45, 837-839.

Koch, C., Kroppenstedt, R. M., Rainey, F. A. \& Stackebrandt, E. (1996). $16 \mathrm{~S}$ ribosomal DNA analysis of the genera Micromonospora, Actinoplanes, Catellatospora, Catenuloplanes, Couchioplanes, 
Dactylosporangium, and Pilimelia and emendation of the family Micromonosporaceae. Int J Syst Bacteriol 46, 765-768.

Korn-Wendisch, F., Rainey, F. A., Kroppenstedt, R. M., Kempf, A., Majazza, A., Kutzner, H. J. \& Stackebrandt, E. (1995). Thermocrispum gen. nov., a new genus of the order Actinomycetales, and description of Thermocrispum municipale sp. nov. and Thermocrispum agreste sp. nov. Int J Syst Bacteriol 45, 67-77.

Krasil'nikov, N. A. (1938). In Ray Fungi and Related Organisms Actinomycetales. Moscow: Akademiya Nauk SSSR.

Krasil'nikov, N. A., Kalakoutskii, L. V. \& Kirillova, N. F. (1961). A new genus of Actinomycetales, Promicromonospora, gen. nov. Bull Acad Sci USSR Ser Biol 1, 107-112.

Kudo, T., Itoh, T., Miyadoh, S., Shomura, T. \& Seino, A. (1993). Herbidospora gen. nov., a new genus of the family Streptosporangiaceae Goodfellow et al. 1990 Int J Syst Bacteriol 43, 319-328.

Kudo, T., Matsushima, K., Itoh, T., Sasaki, J. \& Suzuki, K. (1998). Description of four new species of the genus Kineosporia: Kineosporia succinea sp. nov., Kineosporia rhizophila sp. nov., Kineosporia mikuniensis sp. nov. and Kineosporia rhamnosa sp. nov., isolated from plant samples, and amended description of the genus Kineosporia. Int J Syst Bacteriol 48, 1245-1255.

La Scola, B., Fenollar, F., Fournier, P. E., Altwegg, M., Mallet, M. N. \& Raoult, D. (2001). Description of Tropheryma whipplei gen. nov., sp. nov., the Whipple's disease bacillus. Int J Syst Evol Microbiol 51, 1471-1479.

Labeda, D. P. (2001). Crossiella gen. nov., a new genus related to Streptoalloteichus. Int J Syst Evol Microbiol 51, 1575-1579.

Labeda, D. P. \& Kroppenstedt, R. M. (2000). Phylogenetic analysis of Saccharothrix and related taxa: proposal for Actinosynnemataceae fam. nov. Int J Syst Evol Microbiol 50, 331-336.

Labeda, D. P. \& Kroppenstedt, R. M. (2005). Stackebrandtia nassauensis gen. nov., sp. nov. and emended description of the family Glycomycetaceae. Int J Syst Evol Microbiol 55, 1687-1691.

Labeda, D. P. \& Kroppenstedt, R. M. (2006). Goodfellowia gen. nov., a new genus of the Pseudonocardineae related to Actinoalloteichus, containing Goodfellowia coeruleoviolacea gen. nov., comb. nov. Int J Syst Evol Microbiol 56, 1203-1207.

Labeda, D. P. \& Kroppenstedt, R. M. (2007). Proposal of Umezawaea gen. nov., a new genus of the Actinosynnemataceae related to Saccharothrix, and transfer of Saccharothrix tangerinus Kinoshita et al. 2000 as Umezawaea tangerina gen. nov., comb. nov Int J Syst Evol Microbiol 57, 2758-2761.

Labeda, D. P. \& Kroppenstedt, R. M. (2008). Proposal for the new genus Allokutzneria gen. nov. within the suborder Pseudonocardineae and transfer of Kibdelosporangium albatum Tomita et al. 1993 as Allokutzneria albata comb. nov Int J Syst Evol Microbiol 58, 1472-1475.

Labeda, D. P., Testa, R. T., Lechevalier, M. P. \& Lechevalier, H. A. (1984). Saccharothrix, a new genus of the Actinomycetales related to Nocardiopsis. Int J Syst Bacteriol 34, 426-431.

Labeda, D. P., Testa, R. T., Lechevalier, M. P. \& Lechevalier, H. A. (1985). Glycomyces, a new genus of the Actinomycetales. Int J Syst Bacteriol 35, 417-421.

Labeda, D. P., Hatano, K., Kroppenstedt, R. M. \& Tamura, T. (2001). Revival of the genus Lentzea and proposal for Lechevalieria gen. nov. Int J Syst Evol Microbiol 51, 1045-1050.

Labeda, D. P., Kroppenstedt, R. M., Euzéby, J. P. \& Tindall, B. J. (2008). Proposal of Goodfellowiella gen. nov. to replace the illegitimate genus name Goodfellowia Labeda and Kroppenstedt 2006. Int J Syst Evol Microbiol 58, 1047-1048.

Lacey, J. \& Goodfellow, M. (1975). A novel actinomycete from sugar cane bagasse, Saccharopolyspora hirsuta gen. et sp. nov. J Gen Microbiol 88, 75-85.
Lawson, P. A., Falsen, E., Akervall, E., Vandamme, P. \& Collins, M. D. (1997). Characterization of some Actinomyces-like isolates from human clinical specimens, reclassification of Actinomyces suis (Soltys and Spratling) as Actinobaculum suis comb. nov. and description of Actinobaculum schaalii sp. nov. Int J Syst Bacteriol 47, 899-903.

Lechevalier, M. P. (1972). Description of a new species, Oerskovia xanthineolytica, and emendation of Oerskovia Prauser et al. Int J Syst Bacteriol 22, 260-264.

Lechevalier, H. A. \& Lechevalier, M. P. (1970). A critical evaluation of the genera of aerobic actinomycetes. In The Actinomycetales, pp. 393405. Edited by H. Prauser. Jena: VEB Gustav Fischer.

Lechevalier, M. P., Lechevalier, H. A. \& Holbert, P. E. (1968). Sporichthya, un nouveau genre de Streptomycetaceae. Ann Inst Pasteur (Paris) 114, 277-286 (in French).

Lechevalier, M. P., Prauser, H., Labeda, D. P. \& Ruan, J.-S. (1986). Two new genera of nocardioform actinomycetes, Amycolata gen. nov. and Amycolatopsis gen. nov. Int J Syst Bacteriol 36, 29-37.

Lee, S.-D. (2006). Phycicoccus jejuensis gen. nov., sp. nov., an actinomycete isolated from seaweed. Int J Syst Evol Microbiol 56, 2369-2373.

Lee, S.-D. (2007). Labedella gwakjiensis gen. nov., sp. nov., a novel actinomycete of the family Microbacteriaceae. Int J Syst Evol Microbiol 57, 2498-2502.

Lee, S.-D. \& Hah, Y.-C. (2002). Proposal to transfer Catellatospora ferruginea and 'Catellatospora ishikariense' to Asanoa gen. nov. as Asanoa ferruginea comb. nov. and Asanoa ishikariensis sp. nov., with emended description of the genus Catellatospora. Int J Syst Evol Microbiol 52, 967-972.

Lee, S.-D. \& Lee, D.-W. (2007). Lapillicoccus jejuensis gen. nov., sp. nov., a novel actinobacterium of the family Intrasporangiaceae, isolated from stone. Int J Syst Evol Microbiol 57, 2794-2798.

Lee, S.-D., Park, S.-K., Yun, Y.-W. \& Lee, D.-W. (2008a). Saxeibacter lacteus gen. nov., sp. nov., an actinobacterium isolated from rock. Int J Syst Evol Microbiol 58, 906-909.

Lee, D.-W., Lee, J.-M., Seo, J.-P., Schumann, P., Kim, S.-J. \& Lee, S.-D. (2008b). Phycicola gilvus gen. nov., sp. nov., an actinobacterium isolated from living seaweed. Int J Syst Evol Microbiol 58, 1318-1323.

Lehmann, K. B. \& Neumann, R. (1896). Atlas und Grundriss der Bakteriologie und Lehrbuch der speziellen bakteriologischen Diagnostik. Munich: J. F. Lehmann (in German).

Lehmann, K. B. \& Neumann, R. (1907). Lehmann's Medizin Handatlanten, X, Atlas und Grundriss der Bakteriologie und Lehrbuch der speziellen bakteriologischen Diagnostik, 4th edn. Munich: J. F. Lehmann (in German).

Li, W.-J., Xu, P., Zhang, L.-P., Tang, S.-K., Cui, X.-L., Mao, P.-H., Xu, L.-H., Schumann, P., Stackebrandt, E. \& Jiang, C.-L. (2003a). Streptomonospora alba sp. nov., a novel halophilic actinomycete, and emended description of the genus Streptomonospora Cui et al. 2001 Int J Syst Evol Microbiol 53, 1421-1425.

Li, W.-J., Xu, P., Tang, S.-K., Xu, L.-H., Kroppenstedt, R. M., Stackebrandt, E. \& Jiang, C.-L. (2003b). Prauserella halophila sp. nov. and Prauserella alba sp. nov., moderately halophilic actinomycetes from saline soil. Int J Syst Evol Microbiol 53, 1545-1549.

Li, W.-J., Chen, H.-H., Xu, P., Zhang, Y.-O., Schumann, P., Tang, S.-K., Xu, L.-H. \& Jiang, C.-L. (2004). Yania halotolerans gen. nov., sp. nov., a novel member of the suborder Micrococcineae from saline soil in China. Int J Syst Evol Microbiol 54, 525-531.

Li, W.-J., Chen, H.-H., Kim, C.-J., Zhang, Y.-Q., Park, D.-J., Lee, J.-C., Xu, L.-H. \& Jiang, C.-L. (2005a). Nesterenkonia sandarakina sp. nov. and Nesterenkonia lutea sp. nov., two novel actinobacteria, and 
emended description of the genus Nesterenkonia. Int J Syst Evol Microbiol 55, 463-466.

Li, W.-J., Schumann, P., Zhang, Y.-Q., Xu, P., Chen, G.-Z., Xu, L.-H., Stackebrandt, E. \& Jiang, C.-L. (2005b). Proposal of Yaniaceae fam. nov. and Yania flava sp. nov. and emended description of the genus Yania. Int J Syst Evol Microbiol 55, 1933-1938.

Li, W.-J., Zhi, X.-Y \& Euzéby, J. P. (2008). Proposal of Yaniellaceae fam. nov., Yaniella gen. nov. and Sinobaca gen. nov. as replacements for the illegitimate prokaryotic names Yaniaceae Li et al. 2005, Yania Li et al. 2004, emend. Li et al. 2005, and Sinococcus Li et al. 2006, respectively Int J Syst Evol Microbiol 58, 525-527.

Liu, W.-T., Hanada, S., Marsh, T. L., Kamagata, Y. \& Nakamura, K. (2002). Kineosphaera limosa gen. nov., sp. nov., a novel Gram-positive polyhydroxyalkanoate-accumulating coccus isolated from activated sludge. Int J Syst Evol Microbiol 52, 1845-1849.

Ludwig, W. \& Klenk, H.-P. (2001). Overview: a phylogenetic backbone and taxonomic framework for procaryotic systematics. In Bergey's Manual of Systematic Bacteriology, 2nd edn, vol. 1, pp. 49-65. Edited by D. R. Boone, R. W. Castenholz \& G. M. Garrity. New York: Springer.

Luedemann, G. (1968). Geodermatophilus, a new genus of the Dermatophilaceae (Actinomycetales). J Bacteriol 96, 1848-1858.

Maldonado, L. A., Fenical, W., Jensen, P. R., Kauffman, C. A., Mincer, T. J., Ward, A. C., Bull, A. T. \& Goodfellow, M. (2005). Salinispora arenicola gen. nov., sp. nov. and Salinispora tropica sp. nov., obligate marine actinomycetes belonging to the family Micromonosporaceae. Int J Syst Evol Microbiol 55, 1759-1766.

Manaia, C. M., Nogales, B., Weiss, N. \& Nunes, O. C. (2004). Gulosibacter molinativorax gen. nov., sp. nov., a molinate-degrading bacterium, and classification of 'Brevibacterium helvolum' DSM 20419 as Pseudoclavibacter helvolus gen. nov., sp. nov. Int J Syst Evol Microbiol 54, 783-789.

Männistö, M. K., Schumann, P., Rainey, F. A., Kämpfer, P., Tsitko, I., Tiirola, M. A. \& Salkinoja-Salonen, M. S. (2000). Subtercola boreus gen. nov., sp. nov. and Subtercola frigoramans sp. nov., two new psychrophilic actinobacteria isolated from boreal groundwater. Int $J$ Syst Evol Microbiol 50, 1731-1739.

Martin, K., Schumann, P., Rainey, F. A., Schuetze, B. \& Groth, I. (1997). Janibacter limosus gen. nov., sp. nov., a new actinomycete with mesodiaminopimelic acid in the cell wall. Int J Syst Bacteriol 47, 529-534.

Maruo, T., Sakamoto, M., Ito, C., Toda, T. \& Benno, Y. (2008). Adlercreutzia equolifaciens gen. nov., sp. nov., an equol-producing bacterium isolated from human faeces, and emended description of the genus Eggerthella. Int J Syst Evol Microbiol 58, 1221-1227.

Maszenan, A. M., Seviour, R. J., Patel, B. K. C., Schumann, P. \& Rees, G. N. (1999). Tessaracoccus bendigoensis gen. nov., sp. nov., a Grampositive coccus occurring in regular packages or tetrads, isolated from activated sludge biomass. Int J Syst Bacteriol 49, 459-468.

Maszenan, A. M., Seviour, R. J., Patel, B. K. C., Schumann, P., Burghardt, J., Tokiwa, Y. \& Stratton, H. M. (2000). Three isolates of novel polyphosphate-accumulating Gram-positive cocci, obtained from activated sludge, belong to a new genus, Tetrasphaera gen. nov., and description of two new species, Tetrasphaera japonica sp. nov. and Tetrasphaera australiensis sp. nov. Int J Syst Evol Microbiol 50, 593-603.

Maszenan, A. M., Tay, J.-H., Schumann, P., Jiang, H.-L. \& Tay, S. T.-L. (2005). Quadrisphaera granulorum gen. nov., sp, nov., a Gram-positive polyphosphate-accumulating coccus in tetrads or aggregates isolated from aerobic granules. Int J Syst Evol Microbiol 55, 1771-1777.

Maszenan, A. M., Jiang, H.-L., Tay, J. H., Schumann, P., Kroppenstedt, R. M. \& Tay, S. T. (2007). Granulicoccus phenolivorans gen. nov., sp. nov., a Gram-positive, phenol-degrading coccus isolated from phenol-degrading aerobic granules. Int J Syst Evol Microbiol 57, $730-737$.
Matsumoto, A., Takahashi, Y., Shinose, M., Seino, A., Iwai, Y. \& Ōmura, S. (2003). Longispora albida gen. nov., sp. nov., a novel genus of the family Micromonosporaceae. Int J Syst Evol Microbiol 53, 1553-1559.

Matsumoto, A., Yamada, M., Ōmura, S. \& Takahashi, Y. (2008). Microterricola viridarii gen. nov., sp. nov., a new member of the family Microbacteriaceae. Int J Syst Evol Microbiol 58, 1019-1023.

Mevs, U., Stackebrandt, E., Schumann, P., Gallikowski, C. A. \& Hirsch, P. (2000). Modestobacter multiseptatus gen. nov., sp. nov., a budding actinomycete from soils of the Asgard Range (Transantarctic Mountains). Int J Syst Evol Microbiol 50, 337-346.

Meyer, J. (1976). Nocardiopsis, a new genus of the order Actinomycetales. Int J Syst Bacteriol 26, 487-493.

Miller, E. S., Woese, C. R. \& Brenner, S. (1991). Description of the erythromycin-producing bacterium Arthrobacter sp. strain NRRL B3381 as Aeromicrobium erythreum gen. nov., sp. nov. Int J Syst Bacteriol 41, 363-368.

Mohagheghi, A., Grohmann, K., Himmel, M., Leighton, L. \& Updegraff, D. M. (1986). Isolation and characterization of Acidothermus cellulolyticus gen. nov., sp. nov., a new genus of thermophilic, acidophilic, cellulolytic bacteria. Int J Syst Bacteriol 36, 435-443.

Monciardini, P., Cavaletti, L., Schumann, P., Rohde, M. \& Donadio, S. (2003). Conexibacter woesei gen. nov., sp. nov., a novel representative of a deep evolutionary line of descent within the class Actinobacteria. Int J Syst Evol Microbiol 53, 569-576.

Nakamura, K., Hiraishi, A., Yoshimi, Y., Kawaharasaki, M., Masuda, K. \& Kamagata, Y. (1995). Microlunatus phosphovorus gen. nov., sp. nov., a new gram-positive polyphosphate-accumulating bacterium isolated from activated sludge. Int J Syst Bacteriol 45, 17-22.

Nakazawa, F., Poco, S. E., Ikeda, T., Sato, M., Kalfas, S., Sundqvist, G. \& Hoshino, E. (1999). Cryptobacterium curtum gen. nov., sp. nov., a new genus of Gram-positive anaerobic rod isolated from human oral cavities. Int J Syst Bacteriol 49, 1193-1200.

Nesterenko, O., Krassilnikov, E. I. \& Nogina, T. M. (1985). Nocardioidaceae fam. nov., a new family of the order Actinomycetales Buchanan 1917. Mikrobiol Zh 47, 3-12.

Nonomura, H. \& Ohara, Y. (1957). Distribution of actinomycetes in soil. II. Microbispora, a new genus of Streptomycetaceae. J Ferment Technol 35, 307-311.

Nonomura, H. \& Ohara, Y. (1971). Distribution of actinomycetes in soil. X. New genus and species of monosporic actinomycetes. $J$ Ferment Technol 49, 895-903.

Normand, P. (2006). Geodermatophilaceae fam. nov., a formal description. Int J Syst Evol Microbiol 56, 2277-2278.

Normand, P., Orso, S., Cournoyer, B., Jeannin, P., Chapelon, C., Dawson, J., Evtushenko, L. \& Misra, A. K. (1996). Molecular phylogeny of the genus Frankia and related genera and emendation of the family Frankiaceae. Int J Syst Bacteriol 46, 1-9.

Ōmura, S., Takahashi, Y., Iwai, Y. \& Tanaka, H. (1982). Kitasatosporia, a new genus of the order Actinomycetales. J Antibiot (Tokyo) 35, 10131019.

Orla-Jensen, S. (1909). Die Hauptlinien des natürlichen Bakteriensystems Zentralbl Bakteriol Parasitenkd Infektionskr Hyg Abt 2 22, 305346 (in German).

Orla-Jensen, S. (1919). The Lactic Acid Bacteria. Copenhagen: Høst and Son.

Orla-Jensen, S. (1924). La classification des bactéries lactiques. Lait 4, 468-474 (in French).

Ørskov, J. (1923). Investigations into the Morphology of the Ray Fungi. Copenhagen: Levin and Munksgaard.

Pagani, H. \& Parenti, F. (1978). Kineosporia, a new genus of the order Actinomycetales. Int J Syst Bacteriol 28, 401-406. 
Park, Y.-H., Suzuki, K., Yim, D.-G., Lee, K.-C., Yoon, J., Kim, S., Kho, Y.-H., Goodfellow, M. \& Komagata, K. (1993). Suprageneric classification of peptidoglycan group B actinomycetes by sequencing of 5S ribosomal RNA. Antonie van Leeuwenhoek 64, 307-313.

Park, Y.-H., Yoon, J.-H., Shin, Y.-K., Suzuki, K., Kudo, T., Seino, A., Kim, H.-J., Lee, J.-S. \& Lee, S.-T. (1999). Classification of 'Nocardioides fulvus' IFO 14399 and Nocardioides sp. ATCC 39419 in Kribbella gen. nov., as Kribbella flavida sp. nov. and Kribbella sandramycini sp. nov. Int J Syst Bacteriol 49, 743-752.

Posada, D. \& Hasegawa, M. (1998). Modeltest: testing the model of DNA substitution. Bioinformatics 14, 817-818.

Prauser, H. (1976). Nocardioides, a new genus of the order Actinomycetales. Int J Syst Bacteriol 26, 58-65.

Prauser, H., Lechevalier, M. P. \& Lechevalier, H. A. (1970). Description of Oerskovia gen. n. to harbor Ørskov's motile nocardia. Appl Microbiol 19, 534.

Prauser, H., Schumann, P., Rainey, F. A., Kroppenstedt, R. M. \& Stackebrandt, E. (1997). Terracoccus luteus gen. nov., sp. nov., an LLdiaminopimelic acid-containing coccoid actinomycete from soil. Int $J$ Syst Bacteriol 47, 1218-1224.

Pribram, E. (1929). A contribution to the classification of microorganisms. J Bacteriol 18, 361-394.

Pukall, R., Schumann, P., Schutte, C., Gols, R. \& Dicke, M. (2006). Acaricomes phytoseiuli gen. nov., sp. nov., isolated from the predatory mite Phytoseiulus persimilis. Int J Syst Evol Microbiol 56, 465-469.

Rainey, F. A., Klatte, S., Kroppenstedt, R. M. \& Stackebrandt, E. (1995). Dietzia, a new genus including Dietzia maris comb. nov., formerly Rhodococcus maris. Int J Syst Bacteriol 45, 32-36.

Rainey, F. A., Ward-Rainey, N., Kroppenstedt, R. M. \& Stackebrandt, E. (1996). The genus Nocardiopsis represents a phylogenetically coherent taxon and a distinct actinomycete lineage: proposal of Nocardiopsaceae fam. nov. Int J Syst Bacteriol 46, 1088-1092.

Rheims, H., Schumann, P., Rohde, M. \& Stackebrandt, E. (1998). Verrucosispora gifhornensis gen. nov., sp. nov., a new member of the actinobacterial family Micromonosporaceae. Int J Syst Bacteriol 48, 1119-1127.

Rivas, R., Sánchez, M., Trujillo, M. E., Zurdo-Piñeiro, J. L., Mateos, P. F., Martínez-Molina, E. \& Velázquez, E. (2003). Xylanimonas cellulosilytica gen. nov., sp. nov., a xylanolytic bacterium isolated from a decayed tree (Ulmus nigra). Int J Syst Evol Microbiol 53, 99-103.

Rivas, R., Trujillo, M. E., Schumann, P., Kroppenstedt, R. M., Sánchez, M., Mateos, P. F., Martinez-Molina, E. \& Velázquez, E. (2004). Xylanibacterium ulmi gen. nov., sp. nov., a novel xylanolytic bacterium of the family Promicromonosporaceae. Int J Syst Evol Microbiol 54, 557-561.

Rocourt, J., Wehmeyer, U. \& Stackebrandt, E. (1987). Transfer of Listeria denitrificans to a new genus, Jonesia gen. nov., as Jonesia denitrificans comb. nov. Int J Syst Bacteriol 37, 266-270.

Runmao, H., Guizhen, W. \& Junying, L. (1993). A new genus of actinomycetes, Planotetraspora gen. nov. Int J Syst Bacteriol 43, 468-470.

Sanders, J. E. \& Fryer, J. L. (1980). Renibacterium salmoninarum gen. nov., sp. nov., the causative agent of bacterial kidney disease in salmonid fishes. Int J Syst Bacteriol 30, 496-502.

Schumann, P., Prauser, H., Rainey, F. A., Stackebrandt, E. \& Hirsch, P. (1997). Friedmanniella antarctica gen. nov., sp. nov., an LLdiaminopimelic acid-containing actinomycete from Antarctic sandstone. Int J Syst Bacteriol 47, 278-283.

Schumann, P., Weiss, N. \& Stackebrandt, E. (2001). Reclassification of Cellulomonas cellulans (Stackebrandt and Keddie 1986) as Cellulosimicrobium cellulans gen. nov., comb. nov. Int J Syst Evol Microbiol 51, 1007-1010.
Shearer, M. C., Colman, P. M., Ferrin, R. M., Nisbet, L. J. \& Nash, C. H., III (1986). A new genus of the Actinomycetales, Kibdelosporangium aridum gen. nov., sp. nov. Int J Syst Bacteriol 36, 47-54.

Sheridan, P. P., Loveland-Curtze, J., Miteva, V. I. \& Brenchley, J. E. (2003). Rhodoglobus vestalii gen. nov., sp. nov., a novel psychrophilic organism isolated from an Antarctic Dry Valley lake. Int J Syst Evol Microbiol 53, 985-994.

Shintani, T., Liu, W.-T., Hanada, S., Kamagata, Y., Miyaoka, S., Suzuki, T. \& Nakamura, K. (2000). Micropruina glycogenica gen. nov., sp. nov., a new Gram-positive glycogen-accumulating bacterium isolated from activated sludge. Int J Syst Evol Microbiol 50, 201-207.

Simpson, P. J., Ross, R. P., Fitzgerald, G. F. \& Stanton, C. (2004). Bifidobacterium psychraerophilum sp. nov. and Aeriscardovia aeriphila gen. nov., sp. nov. Int J Syst Evol Microbiol 54, 401-406.

Singleton, D. R., Furlong, M. A., Peacock, A. D., White, D. C., Coleman, D. C. \& Whitman, W. B. (2003). Solirubrobacter pauli gen. nov., sp. nov., a mesophilic bacterium within the Rubrobacteridae related to common soil clones. Int J Syst Evol Microbiol 53, 485-490.

Soddell, J. A., Stainsby, F. M., Eales, K. L., Kroppenstedt, R. M., Seviour, R. J. \& Goodfellow, M. (2006). Millisia brevis gen. nov., sp. nov., an actinomycete isolated from activated sludge foam. Int $J$ Syst Evol Microbiol 56, 739-744.

Song, L., Li, W.-J., Wang, Q.-L., Chen, G.-Z., Zhang, Y.-S. \& Xu, L.-H. (2005). Jiangella gansuensis gen. nov., sp. nov., a novel actinomycete from the desert soil in north-west China. Int J Syst Evol Microbiol 55, 881-884.

Sorokin, D. Yu., van Pelt, S., Tourova, T. P. \& Evtushenko, L. I. (2009). Nitriliruptor alkaliphilus gen. nov., sp. nov., a deep-lineage haloalkaliphilic actinobacterium from soda lakes capable of growth on aliphatic nitriles, and proposal of Nitriliruptoraceae fam. nov. and Nitriliruptorales ord. nov. Int J Syst Evol Microbiol 59, 248-253.

Spiegel, C. A. \& Roberts, M. (1984). Mobiluncus gen. nov., Mobiluncus curtisii subsp. curtesii sp. nov., Mobiluncus curtisii subsp. holmesii subsp. nov., and Mobiluncus mulieris sp. nov., curved rods from the human vagina. Int J Syst Bacteriol 34, 177-184.

Stackebrandt, E. (2004). Will we ever understand? The undescribable diversity of the prokaryotes. Acta Microbiol Immunol Hung 51, 449-462.

Stackebrandt, E. \& Kroppenstedt, R. (1987). Union of the genera Actinoplanes Couch, Ampullariella Couch, and Amorphosporangium in a redefined genus Actinoplanes. Syst Appl Microbiol 9, 110-114.

Stackebrandt, E. \& Prauser, H. (1991). Assignment of the genera Cellulomonas, Oerskovia, Promicromonospora, and Jonesia to Cellulomonadaceae fam. nov. Syst Appl Microbiol 14, 261-265.

Stackebrandt, E. \& Schumann, P. (2000). Description of Bogoriellaceae fam. nov., Dermacoccaceae fam. nov., Rarobacteraceae fam. nov. and Sanguibacteraceae fam. nov. and emendation of some families of the suborder Micrococcineae. Int J Syst Evol Microbiol 50, 1279-1285.

Stackebrandt, E. \& Schumann, P. (2004). Reclassification of Promicromonospora pachnodae Cazemier et al. 2004 as Xylanimicrobium pachnodae gen. nov., comb. nov. Int J Syst Evol Microbiol 54, 1383-1386. Stackebrandt, E., Seiler, H. \& Schleifer, K. H. (1982). Union of the genera Cellulomonas Bergey et al. and Oerskovia Prauser et al. in a redefined genus Cellulomonas. Zentralbl Bakteriol Hyg Abt 1 Orig C 3, 401-409.

Stackebrandt, E., Smida, J. \& Collins, M. D. (1988). Evidence of phylogenetic heterogeneity within the genus Rhodococcus, revival of the genus Gordona Tsukamura. J Gen Appl Microbiol 34, 341-348.

Stackebrandt, E., Kroppenstedt, R. M., Jahnke, K.-D., Kemmerling, C. \& Gürtler, H. (1994). Transfer of Streptosporangium viridogriseum (Okuda et al. 1966), Streptosporangium viridogriseum subsp. kofuense (Nonomura and Ohara 1969), and Streptosporangium albidum (Furumai et al. 1968) to Kutzneria gen. nov. as Kutzneria viridogrisea 
comb. nov., Kutzneria kofuensis comb. nov., and Kutzneria albida comb. nov., respectively, and emendation of the genus Streptosporangium. Int J Syst Bacteriol 44, 265-269.

Stackebrandt, E., Koch, C., Gvozdiak, O. \& Schumann, P. (1995). Taxonomic dissection of the genus Micrococcus: Kocuria gen. nov., Nesterenkonia gen. nov., Kytococcus gen. nov., Dermacoccus gen. nov., and Micrococcus Cohn 1872 gen. emend. Int J Syst Bacteriol 45, 682-692.

Stackebrandt, E., Rainey, F. A. \& Ward-Rainey, N. L. (1997). Proposal for a new hierarchic classification system, Actinobacteria classis nov. Int J Syst Bacteriol 47, 479-491.

Stackebrandt, E., Breymann, S., Steiner, U., Prauser, H., Weiss, N. \& Schumann, P. (2002a). Re-evaluation of the status of the genus Oerskovia, reclassification of Promicromonospora enterophila (Jager et al. 1983) as Oerskovia enterophila comb. nov. and description of Oerskovia jenensis sp. nov. and Oerskovia paurometabola sp. nov. Int J Syst Evol Microbiol 52, 1105-1111.

Stackebrandt, E., Schumann, P., Schaal, K. P. \& Weiss, N. (2002b). Propionimicrobium gen. nov., a new genus to accommodate Propionibacterium lymphophilum (Torrey 1916) Johnson and Cummins 1972, $1057^{\mathrm{AL}}$ as Propionimicrobium lymphophilum comb. nov. Int J Syst Evol Microbiol 52, 1925-1927.

Stackebrandt, E., Schumann, P. \& Cui, X.-L. (2004). Reclassification of Cellulosimicrobium variabile Bakalidou et al. 2002 as Isoptericola variabilis gen. nov., comb. nov. Int J Syst Evol Microbiol 54, 685-688.

Suzuki, K., Collins, M. D., lijima, E. \& Komagata, K. (1988). Chemotaxonomic characterization of a radiotolerant bacterium, Arthrobacter radiotolerans: description of Rubrobacter radiotolerans gen. nov., comb. nov. FEMS Microbiol Lett 52, 33-39.

Suzuki, K., Sasaki, J., Uramoto, M., Nakase, T. \& Komagata, K. (1997). Cryobacterium psychrophilum gen. nov., sp. nov., nom. rev., comb. nov., an obligately psychrophilic actinomycete to accommodate "Curtobacterium psychrophilum" Inoue and Komagata 1976. Int J Syst Bacteriol 47, 474-478.

Swofford, D. L. (2002). PAUP*: Phylogenetic analysis using parsimony (and other methods), version 4. Sunderland, MA: Sinauer Associates.

Takahashi, Y., Matsumoto, A., Morisaki, K. \& Ōmura, S. (2006). Patulibacter minatonensis gen. nov., sp. nov., a novel actinobacterium isolated using an agar medium supplemented with superoxide dismutase, and proposal of Patulibacteraceae fam. nov. Int J Syst Evol Microbiol 56, 401-406.

Takeuchi, M. \& Hatano, K. (1998). Union of the genera Microbacterium Orla-Jensen and Aureobacterium Collins et al. in a redefined genus Microbacterium. Int J Syst Bacteriol 48, 739-747.

Takeuchi, M., Weiss, N., Schumann, P. \& Yokota, A. (1996). Leucobacter komagatae gen. nov., sp. nov., a new aerobic grampositive, nonsporulating rod with 2,4-diaminobutyric acid in the cell wall. Int J Syst Bacteriol 46, 967-971.

Tamura, K. \& Nei, M. (1993). Estimation of the number of nucleotide substitutions in the control region of mitochondrial DNA in humans and chimpanzees. Mol Biol Evol 10, 512-526.

Tamura, T. \& Sakane, T. (2004). Planotetraspora silvatica sp. nov. and emended description of the genus Planotetraspora. Int J Syst Evol Microbiol 54, 2053-2056.

Tamura, T., Nakagaito, Y., Nishii, T., Hasegawa, T., Stackebrandt, E. \& Yokota, A. (1994a). A new genus of the order Actinomycetales, Couchioplanes gen. nov., with description of Couchioplanes caeruleus Horan and Brodsky 1986 comb. nov. and Couchioplanes caeruleus subsp. azureus subsp. nov. Int J Syst Bacteriol 44, 193-203.

Tamura, T., Takeuchi, M. \& Yokota, A. (1994b). Luteococcus japonicus gen. nov., sp. nov., a new gram-positive coccus with LL-diaminopimelic acid in the cell wall. Int J Syst Bacteriol 44, 348-356.
Tamura, T., Hayakawa, M. \& Hatano, K. (1997). A new genus of the order Actinomycetales, Spirilliplanes gen. nov., with description of Spirilliplanes yamanashiensis sp. nov. Int J Syst Bacteriol 47, 97-102.

Tamura, T., Hayakawa, M. \& Hatano, K. (1998). A new genus of the order Actinomycetales, Cryptosporangium gen. nov., with descriptions of Cryptosporangium arvum sp. nov. and Cryptosporangium japonicum sp. nov. Int J Syst Bacteriol 48, 995-1005.

Tamura, T., Suzuki, S. \& Hatano, K. (2000a). Acrocarpospora gen. nov., a new genus of the order Actinomycetales. Int J Syst Evol Microbiol 50, 1163-1171.

Tamura, T., Liu, Z., Zhang, Y. \& Hatano, K. (2000b). Actinoalloteichus cyanogriseus gen. nov., sp. nov. Int J Syst Evol Microbiol 50, 1435-1440.

Tamura, T., Hayakawa, M. \& Hatano, K. (2001). A new genus of the order Actinomycetales, Virgosporangium gen. nov., with descriptions of Virgosporangium ochraceum sp. nov. and Virgosporangium aurantiacum sp. nov. Int J Syst Evol Microbiol 51, 1809-1816.

Tamura, T., Hatano, K. \& Suzuki, K. (2006). A new genus of the order Actinomycetales, Polymorphospora gen. nov., with description of Polymorphospora rubra sp. nov. Int J Syst Evol Microbiol 56, 1959-1964.

Tamura, K., Dudley, J., Nei, M. \& Kumar, S. (2007). MEGA4: molecular evolutionary genetics analysis (MEGA) software version 4.0. Mol Biol Evol 24, 1596-1599.

Tang, S. K., Tian, X. P., Zhi, X. Y., Cai, M., Wu, J. Y., Yang, L. L., Xu, L. H. \& Li, W. J. (2008). Haloactinospora alba gen. nov., sp. nov., a halophilic filamentous actinomycete of the family Nocardiopsaceae. Int J Syst Evol Microbiol 58, 2075-2080.

Tao, T.-S., Yue, Y.-Y., Chen, W.-X. \& Chen, W.-F. (2004). Proposal of Nakamurella gen. nov. as a substitute for the bacterial genus Microsphaera Yoshimi et al. 1996 and Nakamurellaceae fam. nov. as a substitute for the illegitimate bacterial family Microsphaeraceae Rainey et al. 1997. Int J Syst Evol Microbiol 54, 999-1000.

Thawai, C., Tanasupawat, S., Itoh, T. \& Kudo, T. (2006). Actinocatenispora thailandica gen. nov., sp. nov., a new member of the family Micromonosporaceae. Int J Syst Evol Microbiol 56, 1789-1794.

Thiemann, J. E. \& Beretta, G. (1968). A new genus of the Actinoplanaceae. Planobispora, gen. nov. Arch Mikrobiol 62, 157-166.

Thiemann, J. E., Pagani, H. \& Beretta, G. (1967a). A new genus of the Actinoplanaceae. Planomonospora, gen. nov. G Microbiol 15, 27-28.

Thiemann, J. E., Pagani, H. \& Beretta, G. (1967b). A new genus of the Actinoplanaceae. Dactylosporangium, gen. nov. Arch Mikrobiol 58, 42-52.

Thiemann, J. E., Pagani, H. \& Beretta, G. (1968). A new genus of Actinomycetales. Microtetraspora, gen. nov. J Gen Microbiol 50, 295-303.

Tiago, I., Pires, C., Mendes, V., Morais, P. V., da Costa, M. \& Veríssimo, A. (2005). Microcella putealis gen. nov., sp. nov., a Grampositive alkaliphilic bacterium isolated from a nonsaline alkaline groundwater. Syst Appl Microbiol 28, 479-487.

Tiago, I., Morais, P. V., da Costa, M. S. \& Veríssimo, A. (2006). Microcella alkaliphila sp. nov., a novel member of the family Microbacteriaceae isolated from a non-saline alkaline groundwater, and emended description of the genus Microcella. Int J Syst Evol Microbiol 56, 2313-2316.

Tomita, K., Nakakita, Y., Hoshino, Y., Numata, K. \& Kawaguchi, H. (1987). New genus of the Actinomycetales: Streptoalloteichus hindustanus gen. nov., nom. rev.; sp. nov., nom. rev. Int J Syst Bacteriol 37, 211-213.

Trevisan, V. (1889). I Generi e le Specie delle Batteriaceae. Milan: Zanaboni and Gabuzzi (in Italian).

Tsukamoto, T., Takeuchi, M., Shida, O., Murata, H. \& Shirata, A. (2001). Proposal of Mycetocola gen. nov. in the family Microbacteriaceae and three new species, Mycetocola saprophilus sp. nov., Mycetocola tolaasinivorans sp. nov. and Mycetocola lacteus sp. nov., isolated from cultivated mushroom, Pleurotus ostreatus. Int J Syst Evol Microbiol 51, 937-944. 
Urzì, C., Salamone, P., Schumann, P. \& Stackebrandt, E. (2000). Marmoricola aurantiacus gen. nov., sp. nov., a coccoid member of the family Nocardioidaceae isolated from a marble statue. Int J Syst Evol Microbiol 50, 529-536.

van Saceghem, R. (1915). Dermatose contagieuse (impétigo contagieux). Bull Soc Pathol Exot 8, 354-359 (in French).

Ventura, M., Canchaya, C., Fitzgerald, G. F., Gupta, R. S. \& van Sinderen, D. (2007). Genomics as a means to understand bacterial phylogeny and ecological adaptation: the case of bifidobacteria. Antonie van Leeuwenhoek 91, 351-372.

von Wintzingerode, F., Göbel, U. B., Siddiqui, R. A., Rösick, U., Schumann, P., Frühling, A., Rohde, M., Pukall, R. \& Stackebrandt, E. (2001). Salana multivorans gen. nov., sp. nov., a novel actinobacterium isolated from an anaerobic bioreactor and capable of selenate reduction. Int J Syst Evol Microbiol 51, 1653-1661.

Wade, W. G., Downes, J., Dymock, D., Hiom, S. J., Weightman, A. J., Dewhirst, F. E., Paster, B. J., Tzellas, N. \& Coleman, B. (1999). The family Coriobacteriaceae: reclassification of Eubacterium exiguum (Poco et al. 1996) and Peptostreptococcus heliotrinreducens (Lanigan 1976) as Slackia exigua gen. nov., comb. nov. and Slackia heliotrinireducens gen. nov., comb. nov., and Eubacterium lentum (Prevot 1938) as Eggerthella lenta gen. nov., comb. nov. Int J Syst Bacteriol 49, 595-600.

Waksman, S. A. \& Henrici, A. T. (1943). The nomenclature and classification of the actinomycetes. J Bacteriol 46, 337-341.

Wang, Y., Zhang, Z.-S. \& Ruan, J.-S. (1996). A proposal to transfer Microbispora bispora (Lechevalier 1965) to a new genus, Thermobispora gen. nov., as Thermobispora bispora comb. nov. Int $J$ Syst Bacteriol 46, 933-938.

Wang, Y. M., Zhang, Z. S., Xu, X. L., Ruan, J. S. \& Wang, Y. (2001). Actinopolymorpha singaporensis gen. nov., sp. nov., a novel actinomycete from the tropical rainforest of Singapore. Int J Syst Evol Microbiol 51, 467-473.

Wellington, E. M. H., Stackebrandt, E., Sanders, D., Wolstrup, J. \& Jorgensen, N. O. G. (1992). Taxonomic status of Kitasatosporia, and proposed unification with Streptomyces on the basis of phenotypic and 16S rRNA analysis and emendation of Streptomyces Waksman and Henrici 1943, 339 ${ }^{\mathrm{AL}}$. Int J Syst Bacteriol 42, 156-160.

Wiese, J., Jiang, Y., Tang, S.-K., Thiel, V., Schmaljohann, R., Xu, L.-H., Jiang, C.-L. \& Imhoff, J. F. (2008). A new member of the family Micromonosporaceae, Planosporangium flavigriseum gen. nov., sp. nov. Int J Syst Evol Microbiol 58, 1324-1331.

Witt, D. \& Stackebrandt, E. (1990). Unification of the genera Streptoverticillum and Streptomyces, and amendation of Streptomyces Waksman and Henrici 1943, 339 $9^{\mathrm{AL}}$. Syst Appl Microbiol 13, 361-371.

Yamada, K. \& Komagata, K. (1972). Taxonomic studies on coryneform bacteria. V. Classification of coryneform bacteria. J Gen Appl Microbiol 18, 417-431.

Yamamoto, N., Sato, S., Saito, K., Hasuo, T., Tadenuma, M., Suzuki, K., Tamaoka, J. \& Komagata, K. (1988). Rarobacter faecitabidus gen. nov., sp. nov., a yeast-lysing coryneform bacterium. Int J Syst Bacteriol 38, 7-11.

Yassin, A. F., Rainey, F. A., Brzezinka, H., Jahnke, K. D., Weissbrodt H., Budzikiewicz, H., Stackebrandt, E. \& Schaal, K. P. (1995). Lentzea gen. nov., a new genus of the order Actinomycetales. Int J Syst Bacteriol 45, 357-363.

Yi, H., Schumann, P., Sohn, K. \& Chun, J. (2004). Serinicoccus marinus gen. nov., sp. nov., a novel actinomycete with L-ornithine and L-serine in the peptidoglycan. Int J Syst Evol Microbiol 54, 1585-1589.
Yi, H., Schumann, P. \& Chun, J. (2007). Demequina aestuarii gen. nov., sp. nov., a novel actinomycete of the suborder Micrococcineae, and reclassification of Cellulomonas fermentans Bagnara et al. 1985 as Actinotalea fermentans gen. nov., comb. nov. Int J Syst Evol Microbiol 57, 151-156.

Yokota, A., Tamura, T., Nishii, T. \& Hasegawa, T. (1993a). Kineococcus aurantiacus gen. nov., sp. nov., a new aerobic, gram-positive, motile coccus with meso-diaminopimelic acid and arabinogalactan in the cell wall. Int J Syst Bacteriol 43, 52-57.

Yokota, A., Tamura, T., Hasegawa, T. \& Huang, L. H. (1993b). Catenuloplanes japonicus gen. nov., sp. nov., nom. rev., a new genus of the order Actinomycetales. Int J Syst Bacteriol 43, 805-812.

Yokota, A., Tamura, T., Weiss, N. \& Stackebrandt, E. (1994). Transfer of Propionibacterium innocuum Pitcher and Collins 1991 to Propioniferax gen. nov. as Propioniferax innocuum comb. nov. Int J Syst Bacteriol 44, 579-582.

Yoon, J.-H., Kang, S.-J., Schumann, P. \& Oh, T.-K. (2006). Yonghaparkia alkaliphila gen. nov., sp. nov., a novel member of the family Microbacteriaceae isolated from an alkaline soil. Int I Syst Evol Microbiol 56, 2415-2420.

Yoon, J.-H., Kang, S.-J., Jung, S.-Y. \& Oh, T.-K. (2007). Humicoccus flavidus gen. nov., sp. nov., isolated from soil. Int J Syst Evol Microbiol 57, 56-59.

Zarilla, K. A. \& Perry, J. J. (1984). Thermoleophilum album gen. nov. and sp. nov., a bacterium obligate for thermophily and n-alkane substrates. Arch Microbiol 137, 286-290.

Zgurskaya, H. I., Evtushenko, L. I., Akimov, V. N., Voyevoda, H. V., Dobrovolskaya, T. G., Lysak, L. V. \& Kalakoutskii, L. V. (1992). Emended description of the genus Agromyces and description of Agromyces cerinus subsp. cerinus sp. nov., subsp. nov., Agromyces cerinus subsp. nitratus sp. nov., subsp. nov., Agromyces fucosus subsp. fucosus sp. nov., subsp. nov., and Agromyces fucosus subsp. hippuratus sp. nov., subsp. nov. Int J Syst Bacteriol 42, 635-641.

Zgurskaya, H. I., Evtushenko, L. I., Akimov, V. N. \& Kalakoutskii, L. V. (1993). Rathayibacter gen. nov., including the species Rathayibacter rathayi comb. nov., Rathayibacter tritici comb. nov., Rathayibacter iranicus comb. nov., and six strains from annual grasses. Int J Syst Bacteriol 43, 143-149.

Zhang, Z., Wang, Y. \& Ruan, J. (1997). A proposal to revive the genus Kitasatospora (Omura, Takahashi, Iwai, and Tanaka 1982). Int J Syst Bacteriol 47, 1048-1054.

Zhang, Z., Wang, Y. \& Ruan, J. (1998). Reclassification of Thermomonospora and Microtetraspora. Int J Syst Bacteriol 48, 411-422.

Zhang, Z., Kudo, T., Nakajima, Y. \& Wang, Y. (2001). Clarification of the relationship between the members of the family Thermomonosporaceae on the basis of $16 \mathrm{~S}$ rDNA, 16S-23S rRNA internal transcribed spacer and $23 \mathrm{~S}$ rDNA sequences and chemotaxonomic analyses. Int J Syst Evol Microbiol 51, 373-383.

Zhang, Y.-Q., Schumann, P., Yu, L.-Y., Liu, H.-Y., Zhang, Y.-Q., Xu, L.-H., Stackebrandt, E., Jiang, C.-L. \& Li, W.-J. (2007a). Zhihengliuella halotolerans gen. nov., sp. nov., a novel member of the family Micrococcaceae. Int J Syst Evol Microbiol 57, 1018-1023.

Zhang, L., Xu, Z. \& Patel, B. K. C. (2007b). Frondicola australicus gen. nov., sp. nov., isolated from decaying leaf litter from a pine forest. Int J Syst Evol Microbiol 57, 1177-1182.

Zopf, W. (1891). Über Ausscheidung von Fettfarbstoffen Lipochromen seitens gewisser Spaltpilze. Ber Dtsch Bot Ges 9, 22-29 (in German). 